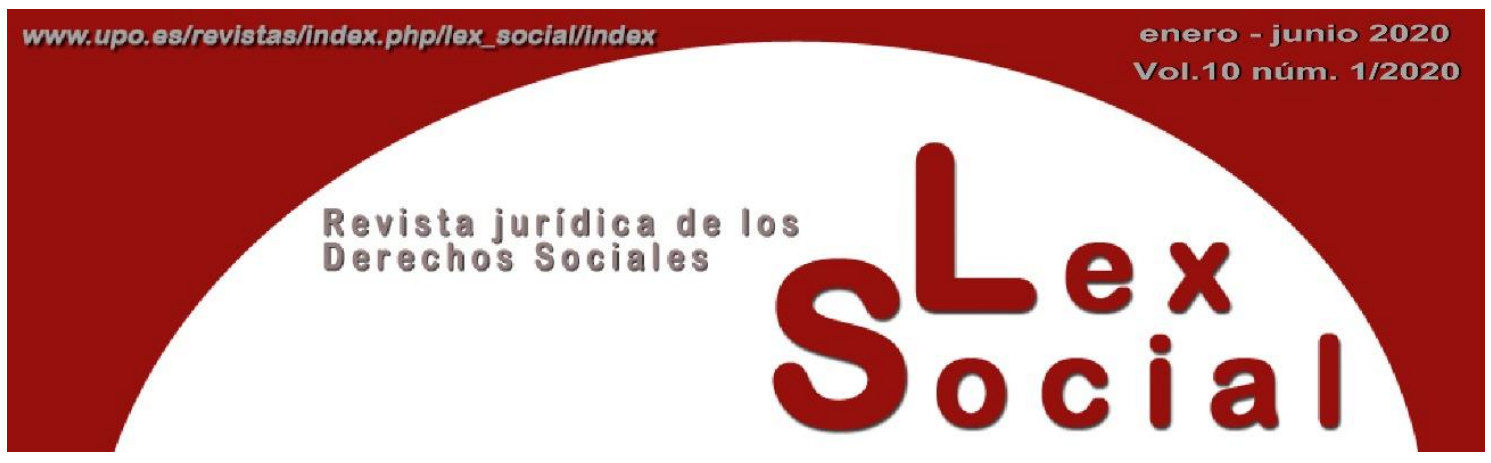

\title{
EL TRABAJO DECENTE COMO OBJETIVO DE DESARROLLO SOSTENIBLE
}

\section{DECENT WORK AS A SUSTAINABLE DEVELOPMENT OBJECTIVE}

\author{
JOSÉ LUIS GIL Y GIL \\ Catedrático de Derecho del Trabajo \\ Universidad de Alcalá
}

Artículo recibido el 6 de noviembre de 2019

Artículo aceptado el 16 de noviembre de 2019

\begin{abstract}
RESUMEN
El concepto-ético jurídico de trabajo decente, que promueve la OIT desde 1999 e institucionaliza la Declaración de la OIT de 2008 sobre la justicia social para una globalización equitativa, es uno de los objetivos de desarrollo sostenible. Dos ideas fundamentales resumen la respuesta de la OIT a la globalización y la crisis económica, y sirven de parámetro para examinar los progresos logrados en la consecución de ese objetivo de desarrollo sostenible y la coherencia de las últimas reformas laborales con los estándares que establece la Organización: proteger los derechos de los trabajadores y situar el empleo y la protección social en el eje de las políticas. En el marco de sus competencias, el Defensor del Pueblo puede contribuir a la promoción del trabajo decente, un objetivo de desarrollo sostenible cuya consecución es todavía lejana, incluso en los países más avanzados.
\end{abstract}

Palabras Clave: Trabajo decente, justicia social, Objetivos de desarrollo sostenible, Organización Internacional del Trabajo.

\section{Abstract}

The ethical-legal concept of decent work, which the ILO has been promoting since 1999 and was institutionalized by the 2008 ILO Declaration on social justice for a fair globalization, is one of the sustainable development goals. Two fundamental ideas 
summarize the ILO's response to globalization and the economic crisis, and serve as a parameter to examine the progress made in achieving that goal of sustainable development and the coherence of the latest labour reforms with the standards established by the Organization: the protection of workers' rights and the employment and social policy as the heart of policies. Within the framework of its authority, the Ombudsman can contribute to the promotion of decent work, a goal of sustainable development whose achievement is still far away, even in the most advanced countries.

KeYWORDS: Decent Work. social justice, Sustainable Development Goals, International Labour Organization.

SUMARIO

Introducción.

1. Protección de los derechos de los trabajadores.

1.1. El diálogo social como método eficaz.

1.2. Los principios y derechos fundamentales en el trabajo como orden público social universal.

2. El empleo y la protección social, eje de las políticas públicas.

\subsection{El empleo como imperativo.}

2.2. La protección social como amortiguador social y estabilizador económico.

Conclusiones.

Bibliografía citada.

\section{Introducción}

El término trabajo decente aparece, por vez primera, en 1999, en el título del Informe del Director General de la OIT, Juan Somavía, a la Conferencia Internacional del Trabajo ${ }^{1}$.

\footnotetext{
${ }^{1}$ OIT, Trabajo decente, Memoria del Director General, Conferencia Internacional del Trabajo, 87a reunión, junio de 1999, Informe I, Ginebra, Oficina Internacional del Trabajo, 1999, 98 pp. Sobre el trabajo decente, vid., por todos, EGGER, P.; SENGENBERGER, W., "Problemas y políticas del trabajo decente", Boletín Técnico Interamericano de Formación Profesional, Boletín Cinterfor/OIT, no 151, 2001, pp. 27-68; GHAI, D. Decent work: Concepts, models and indicators, International Institute for Labour Studies, Discussion Paper Series, Geneva, 2002; “Trabajo decente. Concepto e indicadores", International Labour Review, 2003, 2, pp. 125-160, y Decent work: Universality and Diversity, International Institute for Labour Studies, Discussion Paper Series, Geneva; GHAI, D. (ed.), Decent work: Objectives and Strategies, International Institute for Labour Studies, Geneva, 2006; RODGERS, G. El trabajo decente como una meta para la economía global, «Boletín Cinterfor», 153 (2002), pp. 9-28, y Labour Market Flexibility and Decent Work, «DESA Working Paper», 47 (2007); SERVAIS, J.M., "Política de trabajo decente y mundialización. Reflexiones sobre un planteamiento jurídico renovado", Revista Internacional del Trabajo, Vol. 123, 2004/1-2, pp. 18-53; "La OIT et le travail décent. La difficile médiation entre croissance, création d'emploi
} 
La Declaración sobre la justicia social para una globalización equitativa, de 2008, lo ha institucionalizado como el principio organizativo de las tareas de la OIT y lo ha situado en el centro de las políticas de la Organización para alcanzar sus objetivos constitucionales [I, A) y B) $]^{2}$. A su vez, el Pacto Mundial para el empleo, de 2009, lo considera como la respuesta a la crisis financiera y económica ${ }^{3}$. Por su parte, la Declaración del Centenario para el Futuro del Trabajo, de 2019, reafirma y renueva el objetivo de luchar por la justicia social y el trabajo decente, e institucionaliza el enfoque del futuro del trabajo centrado en el ser humano ${ }^{4}$. En particular, la nueva Declaración precisa que todos los trabajadores deben disfrutar de una protección adecuada de conformidad con el Programa de Trabajo Decente, teniendo en cuenta: el respeto de sus

et protection des travailleurs", Revue de Droit Comparé du Travail et de la Sécurité Sociale, 2011, 1, pp. 71-80, y "El trabajo decente: la visión de la OIT y su puesta en práctica", Relaciones Laborales: Revista Crítica de Teoría y Práctica», 2012, 15-18, pp. 141-166; GODFREY, M. Employment dimensions of decent work: Trade-offs and complementarities, en GHAI, D. (ed.), Decent work: Objectives and Strategies, pp. 77-126; PECCOUD, D. (dir.), El trabajo decente. Puntos de vista filosóficos y espirituales, OIT, Madrid, 2006; SOMAVÍA, J., El Programa de trabajo decente de la OIT como aspiración de las personas: inserción de los valores y la ética en la economía global, en PECCOUD, D. (dir.), El trabajo decente. Puntos de vista filosóficos y espirituales, cit., pp. 3-12; BONNECHÈRE, M., "L'optique du travail décent", Droit Ouvrier, 2007, 2, pp. 57-74, y "Travail décent et 'modernisation' du droit du travail", Travail et Emploi, 2008, 113, pp. 91-115; RODGERS, G.; KUPTSCH, C. (eds.), Pursuing decent work goals: Priorities for research, International Institute for Labour Studies, Geneva, 2008; TREBILCOCK, From social justice to decent work : An overview of the ILO's guiding ideals 1919-2008, ILO Century Project, International Institute for Labour Studies, ILO, Geneva, pp. 22 ss.; BOUTIN, C., De la mondialisation à l'universalisation: une ambition sociale, Rapport intermédiaire au Président de la République, La documentation française, Paris, 2010, pp. 51 ss.; HUGHES, S; HAWORTH, N., The International Labour Organization (ILO). Coming in from the cold, Routledge, Global Institutions, London-New York, 2011, pp. 74 ss.; AUVERGNON, P., "De Declaración en Declaración de la OIT: El trabajo decente, lema de acompañamiento social de la globalización”, Relaciones Laborales: Revista Crítica de Teoría y Práctica, 2012, 15-18, pp. 121-139, y “À propos de la promotion du 'travail décent' par l'OIT”, en MESTRE, CH.; SACHS-DURAND, C. ; STORCK, M. (dirs.), Le travail humain au carrefour du droit et de la sociologie. Hommage en l'honneur du Professeur Nikitas Aliprantis, Pus, Strasburg 2014, pp. 343-364; USHAKOVA, T. "El trabajo decente en el contexto de la migración internacional", Relaciones Laborales: Revista Crítica de Teoría y Práctica, 2012, 15-18, pp. 235-258; GIL, J.L. "Concepto de trabajo decente", ibidem, pp. 77120; "Globalización y empleo: Propuestas de la OIT para un desarrollo sostenible", Revista Doctrinal Aranzadi Social, no 11/2014, parte Doctrina, en www.aranzadidigital.es, BIB 2014\118, 32 pp.; "Il lavoro nella Constituzione e nelle Dichiarazioni dell'OIL", en CORTI, M. (a cura di), Il lavoro nelle carte internazionali, Vita e Pensiero, Ricerche Diritto, Università Cattolica del Sacro Cuore di Milano, 2016, pp. 21-57, y "Trabajo decente y reformas laborales", en GIL, J.L. (coord.), "Eficiencia económica y protección social”, número monográfico de la Revista Derecho Social y Empresa, núm. 7, julio de 2017, Dykinson, Madrid, pp. 21-78.

2 SOMAVÍA, J., Prefacio, en Declaración de la OIT sobre la justicia social para una globalización equitativa, O, Ginebra 2008, p. 1. Cfr. OIT, Declaración de la OIT sobre la justicia social para una globalización equitativa, OIT, Ginebra, 2008, y OIT, Declaración sobre la justicia social para una globalización equitativa. Plan de aplicación preliminar, OIT, Ginebra, 2008.

${ }^{3}$ Vid. OIT, Para recuperarse de la crisis: Un Pacto Mundial para el Empleo, OIT, Ginebra 2009 y, en la doctrina, ERMIDA, O., "Primera lectura del Pacto Mundial para el Empleo de la OIT (2009)", Relaciones Laborales: Revista crítica de teoría y práctica, 2009, 2, pp. 1311-1328; BUSSER, E., "El Pacto Mundial para el Empleo de la OIT: su importancia y potencial para España", Revista de la Fundación $1^{\circ}$ de mayo, 8 de octubre de 2009, pp. 19-23, y HUGHES, S; HAWORTH, N., The International Labour Organization (ILO). Coming in from the cold, op. cit., pp. 90 ss.

${ }^{4}$ Cfr. Preámbulo; I, B; II, A, ii), iii), iv), viii), xii), xiii), xvi) y xvii; II, D, y III, B y C, ii). 
derechos fundamentales; un salario mínimo adecuado, establecido por ley o negociado; límites máximos al tiempo de trabajo, y la seguridad y salud en el trabajo ${ }^{5}$. El trabajo decente ha obtenido el respaldo de las Naciones Unidas, que lo concibe, desde 2005, como uno de los Objetivos de Desarrollo del Milenio y, desde 2015, como uno de los Objetivos de Desarrollo Sostenible (Agenda 2030) ${ }^{6}$.

El trabajo decente, respuesta de la OIT a la globalización y a la crisis económica, es un concepto ético-jurídico y un marco integrador de los pilares del mandato constitucional de la OIT: la promoción del empleo, la protección de los derechos en el trabajo, la extensión de la protección social y el fomento del diálogo social, así como el respeto de la igualdad de oportunidades y trato para todas las mujeres y hombres ${ }^{7}$. El trabajo decente aúna tradición e innovación; invita a un análisis de las complementariedades y posibles contradicciones entre sus componentes ${ }^{8}$, y expresa, de forma concisa, el objetivo de la OIT de luchar por la justicia social en un mundo globalizado. La OIT aspira a dar un rostro humano y una dimensión social a la globalización. Hoy más que nunca, la agravación vertiginosa de las desigualdades y el progreso de las nuevas tecnologías hacen necesario el "régimen de trabajo realmente humano" a que alude el preámbulo de la Constitución de la OIT, interpretado a la luz de la Declaración de Filadelfia, y que se diferencia de otras propuestas en boga sobre el trabajo y el futuro del derecho del trabajo, como la flexiseguridad que propugna la Unión Europea ${ }^{9}$. La justicia social implica un "régimen de trabajo realmente humano", expresión que puede interpretarse en un sentido fuerte o débil ${ }^{10}$. Según la primera interpretación, debe ser realmente humano el trabajo en sí mismo. De acuerdo con la segunda, menos exigente, y que ha prevalecido desde la primera guerra mundial hasta nuestros días, debe ser humano el sistema de trabajo, y no necesariamente el trabajo en cuanto tal. Tal parece ser la idea que tenían en mente los redactores del Tratado de Versalles. Así lo demuestra la versión inglesa del instrumento, que alude a "humane conditions of labour". La exigencia de humanidad no se refiere al

\footnotetext{
5 III, B.

${ }^{6}$ Dentro del Objetivo 1, que hacía referencia a "Erradicar la pobreza extrema y el hambre, uno de los Objetivos de Desarrollo del Milenio era "lograr el empleo pleno y productivo y el trabajo decente para todos, incluidos las mujeres y los jóvenes" (1.2),. El objetivo nº 8 de los Objetivos de Desarrollo Sostenible, sobre "Trabajo decente y crecimiento económico", pretende lograr empleo pleno y productivo y un trabajo decente para todos los hombres y mujeres para 2030.

${ }^{7}$ Para mayores detalles y referencias bibliográficas, vid. GIL, J.L., "Concepto de trabajo decente”, cit.; "Globalización y empleo: Propuestas de la OIT para un desarrollo sostenible", op. cit.; "Il lavoro nella Constituzione e nelle Dichiarazioni dell'OIL”, cit., y "Trabajo decente y reformas laborales”, op. cit.

${ }^{8}$ GHAI, D., Decent work: Universality and Diversity, op. cit., p. 2.

${ }^{9}$ SUPIOT, A., La Gouvernance par les nombres. Cours au Collège de France (2012-2014), Fayard, Paris, 2015, pp. 325 ss, y "Las vías de una verdadera reforma del derecho del trabajo", traducción al castellano, a cargo de GIL, J.L., del prólogo a SUPIOT, A. (dir.), Au-delà de l'emploi: Les voies d'une vraie réforme du droit du travail, Flammarion, Paris, 2016, Derecho de las relaciones laborales, mensual, n. 5, mayo 2016, p. 507.

${ }^{10}$ SUPIOT, A., La Gouvernance par les nombres, op. cit., pp. 329 ss. Sobre el significado de un régimen de trabajo realmente humano, cfr. MUSSO, P. y SUPIOT, A. (dirs.), Qu'est qu'un régime de travail réellement humain?, Hermann, Paris, 2018.
} 
propio trabajo, sino a las condiciones en que se ejecuta la prestación laboral. En este sentido, el parágrafo 2 del preámbulo de la Constitución de la OIT ofrece una lista de las condiciones de trabajo que conviene regular y mejorar. Ninguno de los ejemplos que recoge se refiere al trabajo como tal, sino a su coste, duración o carácter inocuo, así como a la libertad sindical o a la formación profesional. Dicho de otro modo, esas condiciones se refieren a los términos del intercambio salarial, y no a la dimensión cualitativa del trabajo ${ }^{11}$. El resultado del consenso en que se basa el welfare capitalism ha sido una reducción del perímetro de la justicia social a los tres ámbitos que menciona el preámbulo de la Constitución de la OIT: los términos cuantitativos del intercambio salarial (salario, tiempo de trabajo, prestaciones sociales), la seguridad física en el trabajo y, por último, las libertades colectivas (libertad sindical y negociación colectiva) ${ }^{12}$. Por el contrario, la cuestión de la dirección del trabajo se ha situado del lado de la técnica, por considerar que deriva de un criterio de eficacia y no de justicia, que escapa, en consecuencia, a la democracia política y social ${ }^{13}$. Los conceptos fundamentales del derecho del trabajo moderno derivan de esa restricción del ámbito de la justicia social, y han servido para conciliar la cosificación del trabajo, transformado en fuerza de trabajo, y la inserción de un estatuto profesional en el contrato de trabajo, para proteger a la persona del trabajador de los efectos físicos y económicos de esa reificación ${ }^{14}$. Desde hace treinta años, la deconstrucción del derecho del trabajo, que obedece a razones tecnológicas y políticas, ha erosionado la protección que ofrece esa rama del ordenamiento jurídico ${ }^{15}$. Tal deconstrucción es particularmente visible en el derecho de la Unión Europea ${ }^{16}$. El problema que plantea la crisis del Estado social no es, pues, conservar o destruir la herencia fordista, sino instaurar un nuevo compromiso entre la libertad de empresa y la protección de los trabajadores ${ }^{17}$. Desde finales del siglo veinte, tal cuestión ha dado lugar a muchas reflexiones, que, a grandes rasgos, dibujan dos orientaciones posibles: por un lado, la flexiseguridad y, por otro, la de un estado profesional de las personas, que propugna situar el trabajo, y no el mercado, en el centro de la política, analizando de nuevo la cuestión del "régimen de trabajo realmente humano"18. Basta con comparar las

\footnotetext{
${ }^{11}$ SUPIOT, A., La Gouvernance par les nombres, op. cit., p. 333.

${ }^{12}$ SUPIOT, A., La Gouvernance par les nombres, op. cit., p. 335.

${ }^{13}$ SUPIOT, A., La Gouvernance par les nombres, ibidem.

${ }^{14}$ SUPIOT, A., La Gouvernance par les nombres, op. cit., pp. 335 ss.

${ }^{15}$ SUPIOT, A., La Gouvernance par les nombres, op. cit., pp. 337 ss.

${ }^{16}$ SUPIOT, A., La Gouvernance par les nombres, op. cit., pp. 340 ss, y "Las vías de una verdadera reforma del derecho del trabajo", op. cit., p. 501 ss.

${ }^{17}$ SUPIOT, A., La Gouvernance par les nombres, op. cit., p. 344.

${ }^{18}$ SUPIOT, A., La Gouvernance par les nombres, op. cit., pp. 344 ss. Según SUPIOT, la primera propuesta puede apoyarse en el artículo 145 TFUE (antiguo artículo 125 TCE), a cuyo tenor "los Estados miembros y la Unión se esforzarán, de conformidad con el presente título, por desarrollar una estrategia coordinada para el empleo, en particular para potenciar una mano de obra cualificada, formada y adaptable y mercados laborales con capacidad de respuesta al cambio económico, con vistas a lograr los objetivos definidos en el artículo 3 del Tratado de la Unión Europea”. La segunda orientación puede entroncarse con la Declaración de Filadelfia de 1944, que ordena a los Estados que promuevan el empleo de "trabajadores en ocupaciones en que puedan tener la satisfacción de utilizar en la mejor forma posible sus habilidades y conocimiento y
} 
palabras que utilizan las dos propuestas para comprender la diferencia que las separa. La flexiseguridad lleva a razonar en términos de flexibilidad, eficacia económica, mercado, capital humano y empleabilidad; el estado profesional de las personas, en términos de libertad, justicia social, derecho, trabajo y capacidad ${ }^{19}$. Al consagrar un enfoque del futuro del trabajo centrado en el ser humano, la Declaración del Centenario para el Futuro del Trabajo, que ha adoptado la OIT en 2019, puede considerarse como una vuelta al espíritu de Filadelfia ${ }^{20}$, y como el triunfo de la idea de un estado profesional de las personas ${ }^{21}$. En este sentido, el nuevo enfoque puede entroncarse con la idea esencial de que el trabajo no es una mercancía, si se interpreta como una afirmación de la dimensión subjetiva del trabajo, o la preeminencia de la persona del trabajador, como sujeto que trabaja, sobre la dimensión objetiva del trabajo, es decir, sobre el fruto, resultado o producto final del trabajo humano ${ }^{22}$.

Mediante la noción de trabajo decente, la OIT no solo ofrece una respuesta coyuntural ante la crisis, sino un horizonte de recuperación y desarrollo sostenible. Uno de los pilares de la filosofía del trabajo decente es que el desarrollo no es sostenible si se ignoran los derechos de los trabajadores ${ }^{23}$. El progreso económico duradero exige un mínimo de justicia social. A fin de conjugar el desarrollo económico, los derechos en el trabajo y la protección social, la OIT propugna el logro de una justicia social para una globalización más equitativa. La OIT entiende que no debe prevalecer el interés económico, y que no hay que cultivar una ventaja inmediata, sino pensar en las generaciones venideras y en un sistema sostenible a largo plazo. Las normas internacionales del trabajo son un patrimonio para el futuro. No basta con crear empleo, sino que debe ser de calidad. Tampoco debe descuidarse el diálogo social. Hay que proteger a los grupos más vulnerables, como las mujeres y los trabajadores migrantes. La OIT considera que es posible la transición hacia un nuevo modelo de desarrollo, pero solo si las políticas económicas se alinean adecuadamente con las políticas de empleo, y se evitan medidas contraproducentes, como los recortes salariales y las políticas de austeridad mal diseñadas. Las recomendaciones de la OIT frente a la crisis apuntan tanto a las políticas macroeconómicas con impacto en el empleo, como a las políticas más específicas al mandato de la OIT en el ámbito del

de contribuir al máximo al bienestar común" [III, b)], así como con el art 15.1 de la Carta de Derechos fundamentales de la Unión Europea, según el cual "toda persona tiene derecho a trabajar y a ejercer una profesión libremente elegida o aceptada" (apartado primero) (p. 347).

${ }^{19}$ SUPIOT, A., La Gouvernance par les nombres, op. cit., p. 346.

${ }^{20}$ SUPIOT, A., L'esprit de Philadelphie. La justice sociale face au marché total, Seuil, Paris, 2010.

${ }^{21}$ SUPIOT, A., La Gouvernance par les nombres, op. cit., pp. 325 ss., y "Las vías de una verdadera reforma del derecho del trabajo", op. cit., p. 507.

${ }^{22}$ La Comisión para el Futuro del Derecho del Trabajo comienza la argumentación sobre el fortalecimiento de las instituciones del trabajo recordando que "el trabajo no es una mercancía con la que se pueda comerciar en los mercados buscando el mejor postor; los trabajadores son seres humanos con derechos, necesidades y aspiraciones": cfr. Comisión Mundial sobre el Futuro del Trabajo, Trabajar para un futuro más prometedor, OIT, Ginebra, 2019, p. 39.

${ }^{23}$ Vid., al respecto, GIL, J.L., "Globalización y empleo: Propuestas de la OIT para un desarrollo sostenible", op. cit. 
mercado laboral, y que tienen que ver con las políticas de empleo, protección social, fomento del diálogo social y apoyo al cumplimiento de las normas laborales, con el objetivo del trabajo decente. La OIT pone el acento en la dimensión social de la crisis, la coherencia entre la política económica y social y la importancia de respetar los estándares laborales y el diálogo social y de considerar el empleo y la protección social como ejes de las políticas públicas.

La importancia de la perspectiva de la OIT estriba en la búsqueda de un equilibrio entre el cumplimiento de los compromisos internacionales y las necesidades de la situación interna. Ofrece un punto de vista diferente al de otras instituciones internacionales, como el Banco Mundial (BM), el Fondo Monetario Internacional (FMI) o la Organización Mundial del Comercio (OMC), que se hallan dominadas por el pensamiento neoliberal, y exaltan las virtudes del comercio y la globalización y propugnan una reforma permanente del mercado de trabajo para hacerlo más flexible y adaptable a las exigencias de la economía. En particular, las instituciones de Bretton Woods auspician políticas nacionales de ajuste estructural y desregulación general del mercado, incluido el de trabajo. Consideran que un mercado de trabajo muy regulado aumenta los costes laborales $\mathrm{y}$, por tanto, afecta negativamente a la competitividad internacional y desincentiva a los inversores. Ahora bien, la desregulación para aumentar la competitividad deja de ser útil si la aplican todos los países, y produce una race to the bottom o un dumping social generalizado. De ahí la importancia de respetar unos derechos laborales básicos e intangibles. Por eso, el estudio de las propuestas de la OIT ofrece un punto de vista válido para el desarrollo de políticas internacionales y nacionales pertinentes, y para el análisis del modo más idóneo para lograr que la eficacia económica no socave los derechos de los trabajadores ${ }^{24}$.

Resulta interesante y aun obligado analizar las últimas reformas laborales que se han llevado a cabo en países como España a la luz del paradigma del trabajo decente que promueven la OIT y la ONU ${ }^{25}$. Dos ideas fundamentales resumen la respuesta de la OIT

\footnotetext{
${ }^{24}$ Es significativo que el manifiesto que firmó un grupo muy numeroso de catedráticos en contra de la reforma laboral de 2012 llevase por título Por un trabajo decente y unas libertades colectivas plenas. Vid. el texto y la lista de firmantes en El País, 23 de marzo de 2017, y BAYLOS, A., "Detrás del manifiesto de los 55: algunas reflexiones", en http://baylos.blogspot.com.es/2012/04/detras-del-manifiesto-de-los-55algunas.html para una aclaración sobre la génesis de la iniciativa y una interpretación de por qué no la suscribieron otros catedráticos.

${ }^{25}$ Sobre el particular, vid. GIL, J.L. (dir.), Reformas laborales frente a la crisis a la luz de los estándares de la OIT. Un análisis crítico desde las perspectivas internacional, nacional y comparada, Editorial Juruá, Lisboa, 379 pp. y GIL, J.L., "Trabajo decente y reformas laborales”, op. cit. Dos estudios publicados en 2018 analizan el grado de cumplimiento, en España, de los objetivos de desarrollo sostenible. Según el informe del Sustainable Development Solutions Network (SDSN), de la ONU, España no aprueba en la consecución de ninguno de los objetivos de desarrollo sostenible, y se halla en el puesto 25 del mundo en el grado de cumplimiento de los mismos. El documento pone de relieve los niveles elevados de desigualdad, así como el porcentaje inaceptable de población en situación de pobreza y riesgo de exclusión social. Vid. SDG Index and Dashboards Report 2018. Global Responsibilities. Implementing the Goals, Bertelsmann Stiftung and Sustainable Development Solutions Network, July 2018, en especial "Spain", p. 397, y, en la prensa,
} 
a la globalización y la crisis económica, y sirven de parámetro para examinar los progresos logrados en la consecución de ese objetivo de desarrollo sostenible y la coherencia de las últimas reformas laborales con los estándares que establece la Organización: proteger los derechos de los trabajadores (1) y situar el empleo y la protección social en el eje de las políticas (2). En el marco de sus competencias, el Defensor del Pueblo puede contribuir a la consecución del objetivo del trabajo decente.

\section{Protección de los derechos de los trabajadores}

El concepto de trabajo decente, de carácter consensual, dinámico, dialéctico y universal, se funda en una integración de derechos y políticas. En el paradigma del trabajo decente, los derechos en el trabajo y el diálogo social se integran en un marco que incluye otras dimensiones de la política social y económica: las políticas de promoción del empleo y de extensión de la protección social ${ }^{26}$. La igualdad en el trabajo se considera un objetivo transversal. El enfoque basado en los derechos parte de la universalidad, indivisibilidad e interdependencia de los derechos humanos. Las políticas tienen como objetivo que las personas puedan ejercer los derechos. La noción de trabajo decente pretende englobar en un marco común las perspectivas jurídica y económica, la cantidad y calidad del empleo, la seguridad en el trabajo y unos ingresos dignos. Para proteger los derechos de los trabajadores, la OIT concibe el diálogo social como un método eficaz (1.1) y los principios y derechos fundamentales en el trabajo como un orden público social universal o un umbral de protección (1.2).

\subsection{El diálogo social como método eficaz}

La OIT promueve el diálogo social y el tripartismo. La OIT tiene, como característica única entre las Organizaciones Internacionales, su estructura tripartita y el hecho de que los representantes de los trabajadores y empresarios participan, junto con los Estados, en la elaboración de los instrumentos de derecho internacional del trabajo. El diálogo social se concibe como un método eficaz y el mejor modo de articular la relación entre los individuos y sus representantes con la comunidad, a fin de promover los derechos a través de políticas adecuadas. Aunque hay diferentes definiciones del concepto de diálogo social, conviene atenerse a la que ofrece la OIT, que entiende que el diálogo social incluye todos los tipos de negociación, consulta o simple intercambio de información entre representantes de los gobiernos, los empresarios y los trabajadores sobre cuestiones de

AGUDO, A., "España pasa examen ante la ONU: aprueba ni suspende, promete”, El País, 19 de julio de 2018. Vid., asimismo, Observatorio Sostenibilidad \#SOS18, Estado actual de sostenibilidad en España 2018, pp. 2, 3 y 8 ss y, en la prensa, PRIETO, F. y ALFONSO, C., "De la sostenibilidad en un país llamado España en el año 2018”, El País, 13 de julio de 2018. El estudio subraya, que en algunos indicadores, España no solo está mal, sino que va a peor. Son ejemplos el creciente número de trabajadores pobres, o con contratos no deseados de duración determinada.

${ }^{26}$ RODGERS, G., "El trabajo decente como una meta para la economía global”, op. cit., p. 17. 
interés común relativas a la política económica y social ${ }^{27}$. El diálogo social también puede presentarse bajo la forma de un proceso tripartito, en el que el gobierno participa oficialmente en el diálogo, o de relaciones bipartitas entre los sindicatos y las organizaciones empresariales. De acuerdo con la definición de la OIT, el diálogo social se considera como una estructura y un proceso que puede ayudar a resolver cuestiones económicas y sociales importantes, promover el buen gobierno, favorecer la paz y la estabilidad social, y estimular la economía ${ }^{28}$. En el marco de la OIT, el diálogo social se conceptúa desde dos perspectivas principales: como una finalidad en sí misma y como un medio para alcanzar los objetivos estratégicos de la organización ${ }^{29}$.

Desde 1999, constituye uno de los elementos del concepto de trabajo decente ${ }^{30}$. La Declaración sobre la justicia social para una globalización equitativa, de 2008,

\footnotetext{
${ }^{27}$ Vid. "Diálogo social", en la página http://www.ilo.org; OIT, Diálogo social. Discusión recurrente en el marco de la Declaración de la OIT sobre la justicia social para una globalización equitativa, Conferencia internacional del trabajo, $102^{2}$ sesión, 2013, Informe VI, ILC.102/VI, OIT, Ginebra, 2013, p. 5, párrafos 15 y 16; OIT, Le dialogue social tripartite au niveau national. Guide de l'OIT pour une meilleure gouvernance, OIT, Genève, 2013, p. 12, y, asimismo, HESSEL, R. Analyse comparative du dialogue social dans les administrations centrales des États membres de l'UE, Étude de la présidence de l'UE, Direction Générale de l'Administration et de la Fonction Publique, Institut Européen d'Administration Publique, Ministère du Budget, des Comptes Publics et de la Fonction Publique, Collection Études et Perspectives, décembre 2008, p. 8.

${ }^{28}$ En reiteradas ocasiones, la OIT ha reafirmado el diálogo social como un elemento esencial del modelo de gobernanza: vid. OIT, Diálogo social. Discusión recurrente en el marco de la Declaración de la OIT sobre la justicia social para una globalización equitativa, cit., p. 6, párrafo 19, que menciona OIT: Resoluciones (y conclusiones) relativas a las consultas tripartitas a nivel nacional sobre políticas económicas y sociales, Consejo de Administración, 267. ${ }^{a}$ reunión, Ginebra, noviembre de 1996, documento GB.267/ESP/3/1; OIT: Curso que ha de darse a la resolución adoptada por la Conferencia Internacional del Trabajo en su 90. ${ }^{a}$ reunión (2002), Consejo de Administración, 285. ${ }^{a}$ reunión, Ginebra, noviembre de 2002, documento GB.285/7/1; Comisión Mundial sobre la Dimensión Social de la Globalización, Por una globalización equitativa: crear oportunidades para todos (Ginebra, OIT, 2004), pp. 59 y 60, párrafo 240. En particular, en 2008, la Declaración sobre la justicia social para una globalización equitativa recuerda que el tripartismo y el diálogo social entre los gobiernos y las organizaciones representativas de trabajadores y empresarios son esenciales para mantener la cohesión social y traducir el desarrollo económico en progreso social: OIT, Declaración sobre la justicia social para una globalización equitativa, adoptada por la Conferencia Internacional del Trabajo en su nonagésima séptima reunión, Ginebra, 10 de junio de 2008, OIT, Ginebra, 2008, prefacio. En 2009, ante el impacto social durable de la crisis, los mandantes de la OIT adoptaron el Pacto mundial por el empleo, que subraya que el diálogo social "es una base sólida para suscitar la adhesión de los empleadores y de los trabajadores a una acción conjunta con los gobiernos, la cual es indispensable para superar la crisis y llevar adelante una recuperación sostenible": OIT, Para recuperarse de la crisis. Un Pacto Mundial para el Empleo, adoptado por la Conferencia Internacional del Trabajo en su nonagésima octava reunión, 19 de junio de 2009, OIT, Ginebra, 2009, párrafo 16. El pacto insiste en el hecho de que la búsqueda de políticas y soluciones concertadas en un marco tripartito puede contribuir a impedir la nivelación por lo bajo de la protección social.

${ }^{29}$ OIT, Diálogo social. Discusión recurrente en el marco de la Declaración de la OIT sobre la justicia social para una globalización equitativa, op. cit., p. 5, párrafo 15, y GIL, J.L. y USHAKOVA, T., "Le dialogue social sur le mode de l'OIT: consolidation et promotion du tripartisme", en MARTIN, P. (dir.), Le dialogue social, modèles et modalités de la régulation juridique en Europe, Presses Universitaires de Bordeaux, Droit Européen, Bordeaux, 2007, pp. 97-130.

${ }^{30}$ OIT, Trabajo decente, cit., y GIL, J.L., "Concepto de trabajo decente", op. cit., pp. 77 ss.
} 
institucionaliza esa visión ${ }^{31}$. Por su parte, el Preámbulo de la Declaración del Centenario sobre el Futuro del Trabajo, de 2019, reconoce que el diálogo social contribuye a la cohesión global de las sociedades y es crucial para una economía productiva y eficiente. Recalca también que el diálogo social, incluida la negociación colectiva y la cooperación tripartita, es un fundamento esencial de todas las actividades de la OIT y contribuye al éxito de la elaboración de políticas y la toma de decisiones en sus Estados Miembros ${ }^{32}$. La Declaración destaca que la cooperación efectiva en el lugar de trabajo es una herramienta que contribuye a que los lugares de trabajo sean seguros y productivos, de tal manera que se respeten la negociación colectiva y sus resultados sin menoscabar el papel de los sindicatos ${ }^{33}$. Al exhortar a todos los Estados miembros, teniendo en cuenta las circunstancias nacionales, a que colaboren individual y colectivamente, con el apoyo de la OIT, a seguir desarrollando su enfoque del futuro del trabajo centrado en las personas, la Declaración recalca que deben basarse en el tripartismo y el diálogo social ${ }^{34}$. La Declaración también indica que corresponde a la OIT reforzar la capacidad de sus mandantes tripartitos para: promover el desarrollo de organizaciones de interlocutores sociales que sean fuertes y representativas; participar en todos los procesos pertinentes, inclusive con las instituciones, programas y políticas del mercado de trabajo, dentro y fuera de sus fronteras, y abordar todos los principios y derechos fundamentales del trabajo, a todos los niveles, según proceda, mediante mecanismos de diálogo social consolidados, influyentes e inclusivos, con la convicción de que esa representación y ese diálogo contribuyen a la cohesión global de las sociedades y son asuntos de interés público, y que resultan cruciales para una economía que sea productiva y eficiente ${ }^{35}$.

En especial en los periodos históricos difíciles, es importante insistir en el respeto y la utilización de los mecanismos de diálogo social, como la negociación colectiva, cuando proceda en todos los niveles. El diálogo social constituye una base sólida para conseguir la adhesión de los empresarios y trabajadores a una acción conjunta con los gobiernos, indispensable para superar la crisis y sacar adelante una recuperación sostenible. El diálogo social como mecanismo para llegar a un acuerdo inspira confianza, y ofrece garantías para el cumplimiento de los compromisos alcanzados. La propia OIT es un foro apropiado para el diálogo social, debido a sus características estructurales y a los

\footnotetext{
${ }^{31}$ El apartado I, A), iii) de la Declaración resume así el objetivo estratégico: "promover el diálogo social y el tripartismo como los métodos más apropiados para: adaptar la aplicación de los objetivos estratégicos a las necesidades y circunstancias de cada país; traducir el desarrollo económico en progreso social y el progreso social en desarrollo económico; facilitar la creación de consenso respecto de las políticas nacionales e internacionales que inciden en las estrategias y programas en materia de empleo y trabajo decente; y fomentar la eficacia de la legislación y las instituciones laborales, en particular respecto del reconocimiento de la relación de trabajo, la promoción de buenas relaciones laborales y el establecimiento de sistemas eficaces de inspección del trabajo".

${ }^{32} \mathrm{II}, \mathrm{B}$.

${ }^{33} \mathrm{II}, \mathrm{C}$.

${ }^{34}$ III.

${ }^{35} \mathrm{IV}, \mathrm{C}$ 
mecanismos de adopción de las normas. Como un modelo en sí, apoya la creación de espacios de diálogo social a nivel nacional. A su vez, el diálogo social institucionalizado a nivel nacional puede servir de método de formación de decisiones sociolaborales que fomenta el diálogo en la rama o sector de actividad y en la empresa. Por eso, el diálogo social es uno de los principios esenciales para promover la recuperación y el desarrollo sostenible, como destacan los apartados 9.8, 15, 16 y 17 del Pacto Mundial para el Empleo.

En España, desde la transición democrática, hay una larga tradición de diálogo social y concertación social, según procedimientos más o menos formalizados. España cumple las condiciones básicas para el diálogo social: los sindicatos son fuertes e independientes, a pesar de la baja tasa de afiliación; existe la voluntad política de llevar a cabo el diálogo social; se respetan, en general, los derechos fundamentales de la libertad sindical y la negociación colectiva, y hay un apoyo institucional al diálogo. Desde la transición democrática, que se inicia en 1975, después de la muerte del general Franco, se ha desarrollado una política de diálogo y de concertación social y de búsqueda de acuerdo con los sindicatos más representativos. Ha acompañado y se ha visto facilitada por el paso de un sindicalismo de tipo revolucionario a un sindicalismo de negociación. En las últimas décadas, hay habido periodos de diálogo y confrontación y se practican, con más o menos éxito, según los diferentes momentos, varios tipos de diálogo social. Hay formas de diálogo social bipartito y tripartito, que operan con un gran pragmatismo y ausencia de formalismo, y también un diálogo social institucionalizado en el seno de órganos como el Consejo Económico y Social ${ }^{36}$.

Pues bien, en algunos casos, las últimas modificaciones legales suscitan problemas en relación con los principios de la libertad sindical y de la negociación colectiva derivados de los Convenios de la OIT. Alegando una situación de extraordinaria y urgente necesidad, los gobiernos regulan instituciones básicas o suspenden o suprimen derechos laborales o sociales mediante decretos-leyes, y modifican el contenido de los convenios colectivos acordados entre los representantes de los trabajadores y empresarios. Así ha sucedido en España. En el informe núm. 371, de 13-27 de marzo de 2014, el Comité de Libertad Sindical pone en entredicho el procedimiento con arreglo al cual se aprobó la reforma laboral de 2012, por entender que el gobierno español prescindió por completo de la consulta a las organizaciones más representativas de los trabajadores y empresarios. Recuerda la importancia de que la consulta con las organizaciones de trabajadores y de empresarios se produzca con una antelación suficiente y, en particular, en el caso de los proyectos de ley o de Real Decreto-Ley, antes de la aprobación por el gobierno y de la

\footnotetext{
${ }^{36}$ No hay que exagerar la distinción entre el diálogo social bipartito y tripartito. Hay acuerdos tripartitos con una parte de carácter bipartito. Tal es el caso, por ejemplo, del acuerdo social y económico de 2 de febrero de 2011 para el crecimiento, el empleo y la garantía de las pensiones.
} 
tramitación parlamentaria ${ }^{37}$. Y espera que tales principios se respeten plenamente ${ }^{38}$. Indica que "los principios en materia de consulta son válidos también en períodos de crisis que requieren medidas urgentes" ${ }^{39}$, y expresa su expectativa de que, en adelante, se respeten plenamente esos principios "en relación con legislaciones que afecten a los intereses de las organizaciones sindicales y sus afiliados", además de pedir al gobierno "que adopte medidas en ese sentido" 40 . Asimismo, con respecto a la Ley 2/2012, de 29 de junio, y el Real Decreto-ley 20/2012, de 13 de julio, subraya la importancia de que las reglas esenciales del sistema de relaciones laborales y de la negociación colectiva se compartan, en la mayor medida posible, por las organizaciones más representativas de trabajadores y empresarios, e invita, por tanto, al gobierno español a que promueva el diálogo social para conseguir ese objetivo desde la perspectiva de los principios de la libertad sindical y de la negociación colectiva ${ }^{41}$. Más recientemente, la OIT ha señalado que espera que, en todo proceso de fijación del salario mínimo interprofesional, el gobierno español consulte exclusivamente a las organizaciones representativas de trabajadores y empresarios interesadas, y garantice que las mismas tengan pleno conocimiento de todas las informaciones necesarias y cuenten con tiempo suficiente, a los fines de fijar su posición ${ }^{42}$. De igual modo, el Comité Europeo de Derechos Sociales, ha constatado el incumplimiento, por parte del gobierno de España, del derecho a la negociación colectiva que garantiza el artículo 6.2 de la Carta Social Europea de 1961, al no haber establecido un procedimiento de consulta con las organizaciones sindicales antes de aprobar la reforma laboral ${ }^{43}$.

En suma, para la OIT, la crisis económica no es una causa justificativa para vulnerar los convenios internacionales suscritos por España sobre la libertad sindical y el derecho a la negociación colectiva. En lugar de imponer las reformas, el gobierno debió promover un

\footnotetext{
${ }^{37}$ OIT, CLS, Informe núm. 371, de marzo de 2014, párrafo 445.

${ }^{38}$ OIT, CLS, Informe núm. 371, de marzo de 2014, párrafo 446.

${ }^{39}$ OIT, CLS, Informe núm. 371, de marzo de 2014, párrafo 445.

${ }^{40}$ OIT, CLS, Informe núm. 371, de marzo de 2014, párrafo 446.

${ }^{41}$ OIT, CLS, Informe núm. 371, de marzo de 2014, párrafo 455.

${ }^{42}$ Cfr. OIT, "Cuarto informe complementario: Informe del Comité encargado de examinar la reclamación en la que se alega el incumplimiento por España del Convenio sobre la fijación de salarios mínimos, 1970 (núm. 131), presentada en virtud del artículo 24 de la Constitución de la OIT por la Confederación Sindical de Comisiones Obreras (CCOO) y la Confederación Sindical Unión General de Trabajadores (UGT)", Oficina Internacional del Trabajo, Consejo de Administración, 329. ${ }^{a}$ reunión, Ginebra, 9-24 de marzo de 2017, Vigésimo punto del orden del día, Informe del Director General, GB.329/INS/20/4, 15 de marzo de 2017, párrafo 46, p. 13.

${ }^{43}$ European Committee of Social Rights, Conclusions XX-3 (2014) (Spain), January 2015, en relación con el artículo 6.2 de la Carta Social Europea. El Comité concluye que la situación en España no está en conformidad con el artículo $6 \$ 2$ de la Carta de 1961, entre otros motivos, por haberse aprobado el Real Decreto-Ley 3/2012 y la Ley 3/2012, que afectaban de forma muy directa a la negociación colectiva, sin la consulta de los sindicatos y las organizaciones patronales. Declara que "el Comité considera en este contexto que las medidas adoptadas en España son desproporcionadas en relación con los objetivos perseguidos y, por tanto, no cumplen con las condiciones establecidas por el artículo 31 de la Carta de 1961".
} 
proceso de diálogo social efectivo. El gobierno español no ha dado cumplimiento a la recomendación de abrir un proceso de diálogo social sobre los contenidos que introdujo la reforma laboral de 2012, ni ha modificado las reglas que introducen, en la actualidad, límites al derecho a la negociación colectiva incompatibles, en algunos casos, con los compromisos internacionales que ha asumido España en la materia. Así, no hay más remedio que admitir que España ha pasado de ser el paladín del diálogo y la concertación social y la garantía del valor jurídico de los convenios colectivos a compartir una posición incómoda, junto a los Estados que no respetan uno de los principios fundamentales que rigen las relaciones laborales en el plano universal ${ }^{44}$.

$\mathrm{Al}$ respecto, conviene señalar que el éxito o el fracaso del diálogo social no se hallan ligados necesariamente a la ideología del partido en el poder. En la primera fase de los gobiernos socialistas, que comenzó en 1982 y terminó en 1996, hubo un periodo de diálogo social hasta 1986 y otro, más conflictivo, hasta $1994^{45}$. En la época de los gobiernos de Aznar (1996-2004), con el Partido Popular, los cuatro primeros años de gobierno fueron fecundos en el terreno del diálogo social. Por el contrario, los cuatro últimos estuvieron marcados por una degradación de la paz social ${ }^{46}$. En el gobierno socialista de Zapatero (2004-2011), el diálogo social comenzó a debilitarse con la crisis financiera y económica ${ }^{47}$. Ya en el periodo de los gobiernos de Rajoy, la reforma del mercado de trabajo impuesta por el Partido Popular, tras la ruptura del diálogo social ${ }^{48}$, dio lugar a dos huelgas generales ${ }^{49}$. Es pronto aún para saber la suerte que correrá el diálogo social con el nuevo gobierno socialista de Sánchez. En este sentido, es difícil establecer una relación entre la crisis económica y el diálogo social. Frente a la importancia del diálogo social en el periodo de la transición democrática, conviene

\footnotetext{
${ }^{44}$ Vid., este sentido, SANGUINETI, W., "España y los convenios de la OIT sobre libertad sindical y negociación colectiva: de paladín a villano", 29 de marzo de 2014, en el blog https://wilfredosanguineti.wordpress.com/2014/03/29/espana-y-los-convenios-de-la-oit/.

${ }^{45}$ Entre 1986 y 1994, los sindicatos más representativos CC.OO, y UGT convocaron tres huelgas generales: el 14 de diciembre de 1988, contra la reforma del mercado de trabajo; el 28 de mayo de 1992, contra la reforma de las prestaciones por desempleo, y el 27 de enero de 1994, contra la reforma laboral.

${ }^{46}$ Vid. AUVERGNON, P.; GIL, J.L, "Le droit social espagnol au temps des gouvernements Aznar", Droit Social, novembre 2004, pp. 1011-1020. El 20 de junio de 2002, CC.OO. y UGT convocaron una huelga general contra la reforma de las prestaciones por desempleo que había llevado a cabo el gobierno conservador de José María Aznar. El 10 de abril de 2003, UGT, federaciones de CCOO, CGT y CNT provocaron una huelga general en contra de la participación de España en la guerra de Irak y sus consecuencias socioeconómicas.

${ }^{47}$ Entre 2010 y 2012, los sindicatos más representativos CCOO y UGT convocaron tres huelgas generales para protestar contra las reformas del mercado de trabajo: el 29 de septiembre de 2010, el 29 de marzo de 2012 y el 14 de noviembre de 2012. Además, los sindicatos ELA, LAB, CIG, CGT y CNT convocaron una huelga general el 27 de enero de 2011 contra la reforma de las pensiones.

${ }^{48}$ La previsión de un plazo para las negociaciones de los interlocutores es un arma de doble filo. Puede desalentar el diálogo social cuando una de las partes cuenta con la complicidad del gobierno.

${ }^{49}$ Las huelgas tuvieron lugar el 29 de marzo de 2012 para protestar contra la reforma de 19 de febrero, y el 14 de noviembre de 2012, para cuestionar las políticas sociales del gobierno.
} 
advertir la ausencia del mismo durante la reciente crisis financiera y económica ${ }^{50}$. Cabe imaginar que, sea cual sea la ideología del partido en el poder, sobrepasado cierto límite en la reducción de la protección de que gozan los trabajadores, resulta difícil o imposible para los sindicatos asumir el contenido de ciertas reformas laborales. Así, por ejemplo, los sindicatos CC.OO. y UGT se opusieron con dureza a la reforma socialista de 1994, la más profunda que se ha producido en España, junto a la de 2012, y que reforzó también los poderes del empresario y otorgó un mayor peso a la negociación colectiva.

\subsection{Los principios y derechos fundamentales en el trabajo como orden público social universal}

La OIT busca la promoción y cumplimiento de las normas laborales. La organización tiene como objetivo el fomento de los derechos laborales, para lo cual propugna la promoción y cumplimiento de las normas y la realización de los principios y derechos fundamentales en el trabajo. En 1998, la OIT adoptó la Declaración relativa a los principios y derechos fundamentales en el trabajo, en cuya virtud todos los Estados miembros tienen el compromiso, derivado de la mera pertenencia a la OIT, de respetar, promover y hacer realidad, de buena fe y de conformidad con la Constitución, los principios y derechos fundamentales en el trabajo (arts. 1 y 2) ${ }^{51}$. Tales principios y derechos fundamentales, que desarrollan los ocho Convenios esenciales de la OIT, son: la libertad de asociación y la libertad sindical y el reconocimiento efectivo del derecho de negociación colectiva; la eliminación de todas las formas de trabajo forzoso u obligatorio; la abolición efectiva del trabajo infantil y, por último, la eliminación de la discriminación en materia de empleo y ocupación (art. 2). Pese a que ha recibido algunas críticas, la Declaración no trata de establecer una jerarquía formal entre los instrumentos, sino de marcar ciertas pautas de aproximación a los estándares mínimos y de fijar prioridades en la ratificación de los Convenios de la OIT. La Declaración rompe con el self service normativo, y configura un orden público social universal ${ }^{52}$. Con la Declaración de 1998,

\footnotetext{
${ }^{50}$ Sin embargo, la OIT señala que el diálogo social es un proceso constructivo que permite maximizar el impacto de las respuestas a la crisis en relación a las necesidades de la economía real, y que el establecimiento de una cultura de diálogo social es particularmente útil en tiempos de crisis: vid. OIT, Para recuperarse de la crisis. Un Pacto Mundial para el Empleo, cit., II. Principios para promover la recuperación y el desarrollo, párrafo 9, 8), y Diálogo social: negociar colectivamente, identificar las prioridades, estimular la acción, párrafo 15. Vid. OIT, Diálogo social. Discusión recurrente en el marco de la Declaración de la OIT sobre la justicia social para una globalización equitativa, cit., p. 50, párrafos 165 y ss, sobre el diálogo social como una oportunidad bien o mal aprovechada para hacer frente a la crisis financiera y económica.

${ }^{51}$ OIT, Declaración de la OIT relativa a los principios y derechos fundamentales en el trabajo y su seguimiento, adoptada por la Conferencia Internacional del Trabajo en su octogésima sexta reunión, Ginebra, 18 de junio de 1998 (Anexo revisado, 15 de junio de 2010), $2^{a}$ edición con anexo revisado, Oficina Internacional del Trabajo, Ginebra, 2010, 18 pp.

${ }^{52}$ Vid. SUPIOT, A., "La place de la sécurité sociale dans le système des normes internationales du travail", Semaine Sociale Lamy, Supplément, 4 septembre 2006, $\mathrm{n}^{\circ}$ 1272, p. 8, y, ya antes, acerca del self service normativo, SUPIOT, A., "Du nouveau au self service normatif : la responsabilité sociale des entreprises", en AA.VV., Analyse juridique et valeurs en droit social. Mélanges en l'honneur de Jean Pélissier, Dalloz,
} 
la OIT crea una medida de promoción especial para fortalecer la aplicación de los cuatros principios y derechos asociados que se consideran fundamentales para alcanzar la justicia social. De ese modo, junto al enfoque tradicional, consistente en la adopción de normas internacionales del trabajo, la OIT ha seguido otro funcional, basado en la promoción de los principios y derechos fundamentales en el trabajo. Asimismo, la Declaración de la OIT sobre la justicia social para una globalización equitativa, de 2008, reafirma de nuevo la importancia particular de tales derechos, como condiciones que hacen posible la realización de los cuatro objetivos estratégicos de la OIT. La Declaración reconoce los beneficios de la globalización, pero defiende que se realicen nuevos esfuerzos para la aplicación de políticas de trabajo decente. Por tanto, la salida de la crisis debe compaginarse con el cumplimiento de las normas laborales y, en particular, de los principios y derechos fundamentales en el trabajo. En definitiva, las normas internacionales del trabajo constituyen las reglas de juego para la economía global y para superar la crisis. En efecto, ya en la parte de principios y objetivos, el Pacto Mundial para el Empleo acuerda "promover las normas fundamentales del trabajo y otras normas laborales internacionales" (apartado 9.7). Luego, les dedica un capítulo especial, denominado "Fortalecer el respeto de las normas internacionales del trabajo", en el cual se subraya el carácter tuitivo de la normativa laboral y su especial utilidad ante la crisis, "para evitar que se desate una espiral descendente en las condiciones laborales" (apartado 14). En fin, la Declaración del Centenario para el Futuro del Trabajo, de 2019, indica que todos los trabajadores deben disfrutar de una protección adecuada de conformidad con el Programa de Trabajo Decente, teniendo en cuenta el respeto de sus derechos fundamentales, un salario mínimo adecuado, establecido por ley o negociado, límites máximos al tiempo de trabajo, y la seguridad y salud en el trabajo ${ }^{53}$. Como en otros aspectos, la Declaración acoge la propuesta de la Comisión Mundial sobre el Futuro del Trabajo, que exhorta a que se adopte una "Garantía Laboral Universal" que comprenda los derechos fundamentales de los trabajadores, un "salario vital adecuado", límites a las

Paris, pp. 541-558, y, asimismo, RODGERS, G.; LEE, E.; SWEPTSTON, L. y VAN DAELE, J., La OIT y la lucha por la justicia social, 1919-2009, OIT, Ginebra, 2009, p. 235, y GIL, J.L., "Concepto de trabajo decente", op. cit., pp. 6 ss; "The protection of fundamental rights at work: The ILO decent work approach", en CARBY-HALL, J. (ed.), Essays on Human Rights: A Celebration of the Life of Dr Janusz Kochanowski, Ius et Lex, Warsaw, 2014, pp. 192-230; "Justicia social y acción normativa de la OIT", Revista Internacional y Comparada de Relaciones Laborales y Derecho del Empleo, Vol. 3, $\mathrm{n}^{\circ}$ 4, octubre-diciembre de 2015, pp. 26 ss.; "Globalización y universalidad del derecho: la lex mercatoria y el derecho internacional del trabajo en el mercado global”, Revista Internacional y Comparada de Relaciones Laborales y Derecho del Empleo, Vol. 4, n 2 2, abril-junio de 2016, pp. 18 ss; "Il lavoro nella Costituzione e nelle Dichiarazioni dell'OIL", op. cit., pp. 43 ss,; "La dimensión social de la globalización en los instrumentos de la OIT", Revista Internacional y Comparada de Relaciones Laborales y Derecho del Empleo, Vol. 5, $\mathrm{n}^{\circ} 1$, eneromarzo de 2017, pp. 12 ss.; "Trabajo decente y reformas laborales", op. cit., pp. 13 y ss, y "Los principios y derechos fundamentales en el trabajo como orden público social universal", en AA.VV., El futuro del trabajo que queremos, Volumen II, "Conversación IV. La gobernanza del trabajo", Conferencia Nacional Tripartita, 28 de marzo de 2017, Palacio de Zurbano, Madrid, Iniciativa del Centenario de la OIT (19192019), Madrid, Organización Internacional del Trabajo y Ministerio de Empleo y Seguridad Social, 2017, p. 508.

${ }^{53}$ III, B, i), ii), iii) y iv). 
horas de trabajo, y la garantía de la seguridad y salud en el lugar de trabajo ${ }^{54}$. Así pues, al igual que el Preámbulo de la Constitución de la OIT, la Declaración del Centenario identifica la justicia social con las mejores condiciones materiales de trabajo, e indica las materias cuya regulación es competencia de la organización. En la Declaración del Centenario, las condiciones de trabajo humanas a que alude el Preámbulo de la OIT incluyen, como núcleo central o esencial, la protección de los principios y derechos fundamentales en el trabajo que identifica la Declaración de 1998 y, asimismo, un conjunto de condiciones de trabajo básicas, relativas a derechos esenciales, presentes en el derecho del trabajo desde sus orígenes, con la revolución industrial: un salario mínimo adecuado, establecido por ley o negociado; límites máximos al tiempo de trabajo, y una mayor seguridad y salud en el trabajo.

Los principios y derechos fundamentales en el trabajo son universales y se aplican a todas las personas en todos los Estados, con independencia de su nivel de desarrollo económico. Configuran un umbral mínimo de decencia. Que no se incluyeran entre ellos, en la Declaración de 1998, el derecho a un salario digno o a la protección en materia de seguridad y salud laboral, se debió a que no había un consenso suficiente, en la comunidad internacional, acerca del carácter esencial de los mismos para configurar el umbral mínimo de decencia ${ }^{55}$. En la terminología del derecho internacional de los derechos humanos que han elaborado los órganos de vigilancia y control de los instrumentos internacionales de ámbito universal y regional, los Estados tienen la obligación de respetar, proteger y realizar o dar efectividad a los derechos humanos ${ }^{56}$. Las Declaraciones de 1998 y 2008 recogen esa lengua de los derechos humanos. Así, la Declaración de 1998 recuerda que los Estados miembros tienen el compromiso, que deriva de la mera pertenencia a la organización, de respetar, promover y hacer realidad, de buena fe y de conformidad con la Constitución, los principios y derechos fundamentales en el trabajo que recogen los Convenios acerca de la libertad de asociación, la libertad sindical y el derecho a la negociación colectiva, la eliminación del trabajo forzoso, la abolición efectiva del trabajo infantil y la eliminación de la discriminación en materia de empleo y ocupación (arts. 1 y 2). A su vez, la Declaración de 2008 sobre la justicia social para una globalización equitativa exige "respetar, promover y aplicar los principios y derechos fundamentales en el trabajo". En el ámbito de la OIT, la protección de los principios y derechos fundamentales en el trabajo constituye uno de los cuatro objetivos del concepto de trabajo decente. Para defender la Declaración de 1998, se ha dicho que los derechos que no se integran en el compromiso

\footnotetext{
${ }^{54}$ Comisión Mundial sobre el Futuro del Trabajo, op. cit., pp. 39 ss.

${ }^{55}$ RODGERS, G.; LEE, E.; SWEPTSTON, L. y VAN DAELE, J., La OIT y la lucha por la justicia social, 1919-2009, op. cit., p. 42.

${ }^{56}$ Cfr, por ejemplo, la Observación General núm. 18 del Comité de Derechos Económicos, Sociales y Culturales, apartados 22 y ss., y AMNISTÍA INTERNACIONAL, Derechos humanos para la dignidad humana. Una introducción a los derechos económicos, sociales y culturales, Amnistía Internacional, Madrid, 2005, pp. 40 ss.
} 
de 1998, lo hacen por completo en la noción de trabajo decente, y que los cuatro principios y derechos fundamentales en el trabajo que proclama son una condición necesaria, aunque no suficiente, para la realización de otros derechos: son derechos-condición o de realización de otros derechos (enabling rights) ${ }^{57}$. La Declaración sobre la justicia social para una globalización equitativa, de 2008, recoge esa idea, cuando destaca que "revisten particular importancia, no sólo como derechos sino también como condiciones propicias, necesarias para la plena realización de todos los objetivos estratégicos" ${ }^{2}$. Asimismo, la Declaración del Centenario para el Futuro del Trabajo, de 2019, mención la promoción de los derechos de los trabajadores como elemento clave para alcanzar un crecimiento inclusivo y sostenible, y la importancia de prestar una atención especial a la libertad de asociación y la libertad sindical y al reconocimiento efectivo del derecho de negociación colectiva como derechos habilitantes ${ }^{59}$. Es claro el carácter habilitante de la libertad sindical y el derecho a la negociación colectiva. En este sentido, la Declaración de 2008 señala que "la libertad de asociación y la libertad sindical y el reconocimiento efectivo del derecho de negociación colectiva son particularmente importantes para permitir el logro de esos cuatro objetivos estratégicos"60. Sin embargo, en mi opinión, no lo es tanto el carácter habilitador de la prohibición del trabajo infantil o el trabajo forzoso, o el de la igualdad y no discriminación. En cualquier caso, no debe olvidarse que, para la Declaración de 2008, con terminología que se inspira en el carácter de universalidad, indivisibilidad e interdependencia de los derechos humanos, "los cuatro objetivos estratégicos son inseparables, están interrelacionados y se refuerzan mutuamente". La Declaración añade que "la falta de promoción de cualquiera de ellos menoscabaría el logro de los demás", y que, "para obtener un máximo de impacto, los esfuerzos encaminados a promoverlos deberían formar parte de una estrategia global e integrada de la OIT en pro del trabajo decente"61. En fin, las Declaraciones de 1998 y 2008 se

\footnotetext{
${ }^{57}$ Cfr. BRETT, W., "Core labour standards: A level playing field for all countries”, en Fundamental rights at work: Overview and prospects, Labour Education 2001/1, n. 122, p. 3; MAUPAIN, FRANCIS, "La 'valeur ajoutée' de la déclaration relative aux principes et droits fondamentaux au travail pour la cohérence et l'efficacité de l'action normative de l'OIT", en DAUGAREILH, I. (dir.), Mondialisation, travail et droits fondamentaux, Bruylant, Bruxelles, 2005, p. 23, y "Nouvelle fondation ou nouvelle façade ? La déclaration de l'OIT sur la justice sociale pour une mondialisation équitable”, Droits fondamentaux, n. 7, janvier 2008décembre 2009, p. 25 ; DAUGAREILH, I., "Avant-propos. L'impact de la mondialisation sur les droits fondamentaux de l'homme au travail", en DAUGAREILH, I. (dir.), Mondialisation, travail et droits fondamentaux, Bruylant, Bruxelles, p. XVII, y GIL, J.L., "Los principios y derechos fundamentales en el trabajo como orden público social universal", op. cit., p. 508. En opinión de RODGERS, G.; LEE, E.; SWEPTSTON, L. y VAN DAELE, J., La OIT y la lucha por la justicia social, 1919-2009, op. cit., p. 42, cuando se estaba debatiendo la Declaración de 1998, algunos sectores propusieron que se incluyeran también temas como la seguridad y la salud en el trabajo, pero en última instancia se decidió limitarla solo a las primeras cuatro categorías de derechos, por considerarlos derechos "habilitadores", es decir, básicos para el logro otros derechos.

$\left.{ }^{58} \mathrm{I}, \mathrm{A}, \mathrm{iv}\right)$.

${ }^{59}$ II, A, vi).

${ }^{60} \mathrm{I}, \mathrm{A}, \mathrm{iv}$.

${ }^{61}$ I, B. El aparado precisa: "La igualdad de género y la no discriminación deben considerarse cuestiones transversales en el marco de los objetivos estratégicos antes mencionados".
} 
pronuncian sobre los vínculos entre los principios y derechos humanos en el trabajo y el proteccionismo comercial. La Declaración de 1998 “subraya que las normas del trabajo no deberían utilizarse con fines comerciales proteccionistas y que nada en la presente Declaración y su seguimiento podrá invocarse ni utilizarse de otro modo con dichos fines; además, no debería en modo alguno ponerse en cuestión la ventaja comparativa de cualquier país sobre la base de la presente Declaración y su seguimiento" "62. Asimismo, la Declaración de 2008 advierte que "la violación de los principios y derechos fundamentales en el trabajo no puede invocarse ni utilizarse de modo alguno como ventaja comparativa legítima y que las normas del trabajo no deberían utilizarse con fines comerciales proteccionistas" $" 63$.

Dependiendo del punto de vista que se adopte, la Declaración de la OIT de 1998 puede resultar o no satisfactoria ${ }^{64}$. Resulta decepcionante si se analiza como un punto de llegada o como un punto final, en la medida en que no incluye aspectos tradicionales y esenciales del derecho del trabajo, tales como la protección de la seguridad y salud laboral, o la garantía de un salario suficiente. Por el contrario, ofrece motivos de esperanza, si se analiza como un punto de partida y si se pone el acento en la dimensión promocional y no en la relación de jerarquía entre los instrumentos. Cabe entender que el mérito de la Declaración consiste en haber roto con el self-service normativo, que autoriza el sistema de ratificaciones, y puede considerarse como el primer paso en la construcción de un orden público social universal, que refleja el consenso de la comunidad internacional sobre la necesidad de respetar un umbral de protección en un mundo globalizado. En este sentido, posee una relevancia particular el hecho de que la Declaración del Centenario sobre el Futuro del Trabajo abre la puerta a la inclusión, en un futuro inmediato, de la protección de la seguridad y salud en el trabajo entre los principios y derechos fundamentales en el trabajo. A juicio de la Comisión Mundial sobre el Futuro del Trabajo, la comunidad internacional reconoce desde hace mucho tiempo la salud como uno de los derechos humanos, y ha llegado el momento de reconocerla también como un principio y derecho fundamental en el trabajo ${ }^{65}$. Por ahora, la Declaración del Centenario no recoge esa propuesta, que figuraba en el proyecto que se sometió al examen de la Conferencia

\footnotetext{
${ }^{62}$ Apartado 5.

$\left.{ }^{63} \mathrm{I}, \mathrm{A}, \mathrm{iv}\right)$.

${ }^{64}$ GIL, J.L., "Los principios y derechos fundamentales en el trabajo como orden público social universal", op. cit., pp. 510 ss.

${ }^{65}$ Comisión Mundial sobre el Futuro del Trabajo, Trabajar para un futuro más prometedor, op. cit., p. 40, con cita del artículo 25 de la Declaración Universal de Derechos Humanos de 1948, que reconoce el derecho a un nivel de vida adecuado que asegure la salud y el bienestar, y el artículo 7 b) del Pacto Internacional de Derechos Económicos, Sociales y Culturales de 1966, que reconoce el derecho a condiciones de trabajo seguras y saludables. La Comisión recuerda que ese derecho se aplica a la salud física y mental. Acerca de la seguridad y salud en el trabajo en el artículo 7 b) del PIDESC, cfr. Comité de Derechos Económicos, Sociales y Culturales (CDESC), Observación general núm. 23 (2016) sobre el derecho a condiciones de trabajo equitativas y satisfactorias (artículo 7 del Pacto Internacional de Derechos Económicos, Sociales y Culturales), Naciones Unidas, Consejo Económico y Social, E/C.12/GC/23, 27 de abril de 2016, párrafos 25 y ss.
} 
Internacional del Trabajo ${ }^{66}$, por más que reconozca que "las condiciones de trabajo seguras y saludables son fundamentales para el trabajo decente" ${ }^{67}$. Con todo, la OIT podría hacerlo en los próximos meses. La Resolución sobre la Declaración del Centenario de la OIT para el Futuro del Trabajo de 2019, adoptada también, en junio de 2019, por la Conferencia Internacional Trabajo, pide al Consejo de Administración de la OIT que "examine, lo antes posible, propuestas para incluir las condiciones de trabajo seguras y saludables en el marco de la OIT relativo a los principios y derechos fundamentales en el trabajo". En un documento reciente, la propia organización reconoce que la OIT se halla fundada en torno al concepto del trabajo seguro y saludable ${ }^{68}$. La inclusión de la seguridad y salud en el trabajo en el elenco de los principios y derechos humanos en el trabajo sería una prueba de que la Declaración de 1998 no debe considerarse como un punto final o un repliegue de la actividad normativa de la OIT, sino como un punto de partida o un primer paso en la construcción de un orden público social universal, que se imponga a todos los Estados, y que rompe con el self service o pick and choose normativo, que autoriza el carácter voluntario de la ratificación de los instrumentos vinculantes que elabora la OIT $^{69}$. También supondría considerar, como fundamentales, el Convenio núm. 155 sobre seguridad y salud de los trabajadores de 1981, y su Protocolo de 2002; el Convenio núm. 161 sobre los servicios de salud en el trabajo, de 1985, y el Convenio núm. 187 sobre el marco promocional para la seguridad y salud en el trabajo, de $2006^{70}$.

Cabría pensar que, en los países más avanzados, las reformas laborales no han cuestionado los principios y derechos fundamentales básicos a que alude la Declaración de la OIT de 1998. Ahora bien, el análisis del caso español basta para comprobar que

\footnotetext{
${ }^{66}$ En el apartado II, C, el proyecto de declaración para su examen por la Conferencia Internacional del Trabajo disponía: "La seguridad y salud en el trabajo es un principio y derecho fundamental en el trabajo, que se añade a todos los principios y derechos que se enuncian en la Declaración de la OIT relativa a los principios y derechos fundamentales en el trabajo (1998)". Cfr. OIT, Documento final del centenario de la OIT, Informe IV, Cuarto punto del orden del día, Conferencia Internacional del Trabajo, 108. a reunión, 2019, Oficina Internacional del Trabajo, Ginebra, 2019, ILC.108/IV, p. 7.

${ }^{67}$ II, D).

${ }^{68}$ OIT, Seguridad y salud en el centro del futuro del trabajo. Aprovechar 100 años de experiencia, Oficina Internacional del Trabajo, Ginebra, 2019, pp. 10 ss.

${ }^{69}$ GIL, J.L., "Los principios y derechos fundamentales en el trabajo como orden público social universal", op. cit., pp. 509 ss. También la Comisión Mundial para el Futuro del Trabajo, Trabajar para un futuro más prometedor, op. cit., p. 15, advierte: "Entendemos el presente informe como el principio de un camino". Y aclara: "Ya que la OIT agrupa a gobiernos, empleadores y trabajadores de todo el mundo, resulta un organismo idóneo para ser brújula y guía del camino que tenemos por delante".

70 OIT, Seguridad y salud en el centro del futuro del trabajo. Aprovechar 100 años de experiencia, op. cit., p. 16, clasifica los instrumentos de la OIT sobre seguridad y salud en el trabajo en cuatro grupos, e incluye entre los que abordan los principios fundamentales: el Convenio sobre seguridad y salud de los trabajadores, 1981 (núm. 155) y su Protocolo de 2002; el Convenio sobre los servicios de salud en el trabajo, 1985 (núm. 161), y el Convenio sobre el marco promocional para la seguridad y salud en el trabajo, 2006 (núm. 187). Ya antes, ALLI, B.O., Principios fundamentales de salud y seguridad en el trabajo, $2^{\mathrm{a}}$ edición, Ministerio de Trabajo e Inmigración, Colección Informes de la OIT, núm. 83, Madrid, 2002, pp. 36 y 37, había escrito que la política de la OIT sobre seguridad y salud en el trabajo está recogida esencialmente en esos tres Convenios internacionales del trabajo y sus correspondientes Recomendaciones.
} 
persisten las violaciones de los derechos a la libertad sindical y a la negociación colectiva y el derecho de huelga. En el Informe núm. 371, de 13-27 de marzo de 2014, el Comité de Libertad Sindical critica la regulación de la prioridad aplicativa del convenio y de la modificación, en el ámbito de la empresa, de los acuerdos colectivos y convenios estatutarios, mediante una decisión unilateral del empresario o un arbitraje obligatorio ${ }^{71}$. De igual modo, el 23 de julio de 2014, CC.OO. y UGT remitieron al Comité Europeo de Derechos Sociales un informe, en el que alegaban el incumplimiento por parte del Estado español del artículo 6.2 de la Carta Social Europea de 1961, que garantiza el derecho a la negociación colectiva ${ }^{72}$. En las Conclusiones XX-3, de 2014, el Comité Europeo de Derechos Sociales ha constatado el incumplimiento de ese precepto, tanto en lo que hace a la prioridad aplicativa del convenio de empresa, como a la posibilidad de descuelgue, pues "permite a los empleadores de manera unilateral no aplicar condiciones pactadas en los convenios colectivos", como sucede en el artículo 41 del ET con los pactos y acuerdos de empresa ${ }^{73}$. En fin, en el informe núm. 380, que se aprobó en la reunión de los días 27,

\footnotetext{
${ }^{71}$ Vid. OIT, CLS, Informe núm. 371, de marzo de 2014, párrafos 450, 451, 453, 454 y 997 y, para mayores detalles, GIL, J.L:, "L'arbitrage obligatoire en Espagne à l'épreuve du droit international du travail", Revue de Droit Comparé du Travail et de la Sécurité Sociale, Université de Bordeaux, 2014-2, pp. 56-65; "Contrattazione collettiva decentrata e produttività nel settore della produzione di automobili in Spagna", Giornale di diritto del lavoro e di relazioni industriali, n. 146/2015, 2, pp. 295-313, y "Trabajo decente y reformas laborales", op. cit., pp. 33 ss. El nuevo gobierno socialista pretende modificar alguno de los aspectos más controvertidos de la reforma laboral de 2012 y, en particular, por lo que mira al derecho a la negociación colectiva, tiene la intención de reestablecer la ultraactividad de los convenios colectivos, para que no pierdan su vigencia una vez denunciados; limitar la prioridad aplicativa de los convenios de empresa, y devolver el protagonismo a los convenios de rama o sector. Así, los convenios colectivos de empresa solo tendrían preferencia aplicativa en los aspectos de la organización interna, como el horario, los turnos y otros elementos de las condiciones laborales, y no podrían empeorar lo establecido en los convenios colectivos sectoriales en materias como los salarios y la jornada de trabajo. Vid. PASCUAL, R., "Convenios y rentas, lo que Valerio quiere cambiar en el mercado laboral”, Cinco Días, 12 de junio de 2018; GÓMEZ, M. V., "El Gobierno renuncia a derogar toda la reforma laboral por su debilidad parlamentaria", El País, 13 de junio de 2018; "Valerio: 'Hay que priorizar el convenio sectorial sobre el de empresa", Cinco Días, 20 de junio de 2018; SERRALLER, M. y VALVERDE, M., "Quince 'golpes' del Gobierno a las empresas, Expansión, 7 de julio de 2018; GÓMEZ, MANUEL V., "Cambios en la reforma laboral: el convenios sectorial prevalecerá sobre el de empresa para los salarios", El País, 11 de julio de 2018, y ALONSO, C., "Magdalena Valerio abre la vía para acabar con la prevalencia del convenio de empresa", El Economista, 11 de julio de 2018 .

${ }^{72}$ En el escrito, se aducía que un Real decreto-ley había derogado un acuerdo pactado de ámbito estatal por las organizaciones sindicales y empresariales, y lo había sustituido por una regulación mucho más restrictiva de derechos. Además, se señalaba que la reforma laboral impone la primacía del convenio colectivo de empresa frente a los convenios colectivos de ámbito superior, y prohíbe a las organizaciones sindicales y empresariales que puedan alterar esa norma. También se alegaban violaciones en materia del descuelgue no sindical de condiciones pactadas en el convenio colectivo sectorial y sobre la unilateralidad definitiva del empresario en las modificaciones sustanciales de trabajo. Por último, se denunciaba que la regulación que hace la ley de la ultraactividad de los convenios colectivos vulnera el principio de autonomía en la negociación.

73 ECSR, Conclusions XX-3 (2014) (Spain), January 2015, en relación con el artículo 6.2 de la Carta Social Europea. En la doctrina, vid. BAJO, I., "La reforma laboral a la luz de la Carta Social Europea. Convergencias y divergencias entre el Tribunal Constitucional y el Comité Europeo de Derechos Sociales", Revista General de Derecho del Trabajo y de la Seguridad Social, 40, 2015, pp. 153-192, y SALCEDO, $\mathrm{M}^{\mathrm{a}} \mathrm{C}$., "Reformas legislativas, incumplimientos de la Carta Social Europea y su invocación en los órganos judiciales", Fundación Centro de Estudios Andaluces, Sevilla, Colección Actual, 73, julio de 2015, 35 pp,
} 
28 y 10 de noviembre de 2016, el Comité de Libertad Sindical cuestiona la redacción del artículo 315.3 del Código Penal, que se aplica principalmente a las actuaciones de los piquetes de huelga, tanto la anterior como la posterior a la reforma del año 2015, por carecer de la suficiente precisión y ser fuente de inseguridad jurídica en lo que hace a los comportamientos que constituyen una coacción en el contexto de una huelga, y los criterios por los que el órgano judicial puede imponer una pena de prisión ${ }^{74}$.

Como alto comisionado de las Cortes Generales, designado por estas para la defensa de los derechos fundamentales y libertades públicas, el Defensor del Pueblo puede contribuir a la defensa de los derechos a la libertad sindical, derecho a la negociación colectiva y derecho de huelga. En este sentido, goza de competencias para la interposición de los recursos de inconstitucionalidad [art. 162.1 a) CE] y de amparo [art. 162.1 b) CE] y, asimismo, para supervisar la actividad de la Administración, dando cuenta a las Cortes Generales (art. $54 \mathrm{CE}$ ).

\section{El empleo y la protección social, eje de la políticas públicas}

Para hacer frente a la globalización y a las crisis económicas recurrentes y lograr un desarrollo sostenible, la OIT considera el empleo como un imperativo (2.1) y la protección social como un amortiguador social y estabilizador económico (2.2). Sin embargo, las medidas de austeridad que aplican los Estados para lograr la consolidación fiscal y controlar la deuda pública no siempre permiten promover el empleo y mantener la protección social.

\subsection{El empleo como imperativo}

En la idea de trabajo decente, la promoción del empleo ocupa un lugar relevante, sobre todo en un contexto marcado por la globalización y la crisis financiera y económica ${ }^{75}$. Para la mayoría de las personas, el trabajo es esencial para escapar de la pobreza y la exclusión social. Al reconocer que carece de sentido la elaboración de normas del trabajo si no se aborda el tema del empleo, la OIT dedica gran parte de sus programas a la creación de mayores oportunidades para hombres y mujeres, a efectos de garantizar un trabajo y unos ingresos decentes. Para alcanzar esa meta, promueve normas

en https://www.centrodeestudiosandaluces.es/datos/publicaciones/Acc73_ok_22072015.pdf., y "La aplicación de la Carta Social Europea por los órganos jurisdiccionales: cuestiones conflictivas y argumentos para superarlas", Editorial Bomarzo, 4 de octubre de 2015, en http://editorialbomarzo.es/la-aplicacion-dela-carta-social-europea-por-los-organos-jurisdiccionales-cuestiones-conflictivas-y-argumentos-parasuperarlas/.

${ }^{74}$ OIT, CLS, Informe núm. 380, de 27 de octubre - 10 de noviembre de 2016, párrafos 495 ss.

${ }^{75}$ GIL, J.L., "Globalización y empleo: propuestas de la OIT para un desarrollo sostenible", op. cit., y USHAKOVA, T., "La política de empleo de la OIT y su influencia en el modelo español", Trabajo. Revista de la Asociación Estatal de Centros Universitarios de Relaciones Laborales y Ciencias del Trabajo, $\mathrm{n}^{\circ} 30$, Enero-Junio 2014, Universidad de Huelva, Huelva, Junio 2014, pp. 17-34. 
internacionales sobre la política del empleo, que, junto con los programas de cooperación técnica, se dirigen a lograr el pleno empleo, productivo y libremente elegido. Junto al Convenio núm. 122, de 1964, sobre la política de empleo, la OIT ha adoptado otros instrumentos para lograr ese objetivo, como el Convenio núm. 88, de 1948, sobre el servicio del empleo, o el Convenio núm. 181, de 1997, sobre las agencias de empleo privadas. El fomento del crecimiento económico sostenido, inclusivo y sostenible, el empleo pleno y productivo y el trabajo decente para todos, que es el tercer campo de actuación del enfoque del futuro del trabajo centrado en el ser humano, que institucionaliza la Declaración del Centenario de la OIT sobre el Futuro del Trabajo, de 2019, debe lograrse a través de: políticas macroeconómicas orientadas al cumplimiento de ese objetivo; políticas comerciales, industriales y sectoriales que favorezcan el trabajo decente y aumenten la productividad; inversión en infraestructuras y en sectores estratégicos para abordar los factores que generan cambios transformadores en el mundo del trabajo; políticas e incentivos que promuevan el crecimiento económico sostenible e inclusivo, la creación y el desarrollo de empresas sostenibles, la innovación y la transición de la economía informal a la economía formal, y que favorezcan la adecuación de las prácticas empresariales a los objetivos de la Declaración, y políticas y medidas que permitan asegurar una protección adecuada de la privacidad y de los datos personales y responder a los retos y las oportunidades que plantea la transformación digital del trabajo, incluido el trabajo en plataformas, en el mundo del trabajo. La Declaración acoge la propuesta de la Comisión Mundial para el Futuro del Trabajo de transformar las economías para promover el trabajo decente y sostenible y reorientar los incentivos, hacia un modelo empresarial y económico centrado en las personas. Además de referirse a las medidas de fomento y a las políticas que deben coadyuvar al logro de ese fin, la Declaración exige que la OIT, en virtud de su mandato constitucional, asuma una función importante en el sistema multilateral, "a fin de promover la coherencia entre las políticas en cumplimiento de su enfoque del futuro del trabajo centrado en las personas, reconociendo los vínculos sólidos, complejos y cruciales que existen entre las políticas sociales, comerciales, financieras, económicas y medioambientales"76.

La crisis pone en entredicho esa aspiración. El desempleo es una consecuencia, pero también un agravante de la crisis ${ }^{77}$. Hoy en día, la OIT coloca el empleo en un primer plano, para subrayar que, sin él, no puede haber un trabajo decente. Como se desprende del título del Convenio núm. 168, de 1988, la OIT adopta ahora una visión más activa, y pone el énfasis en la promoción del empleo, y no tanto en la prevención del desempleo. Para afrontar ese desafío, resulta necesario un enfoque integral que combine políticas

\footnotetext{
${ }^{76}$ IV, F. Al respecto, la Resolución sobre la Declaración del Centenario de la OIT para el Futuro del Trabajo señala que la Conferencia Internacional del Trabajo "4. Invita al Consejo de Administración a que pida al Director General que presente al Consejo de Administración propuestas destinadas a promover una mayor coherencia en el marco del sistema multilateral".

${ }^{77}$ Destaca este aspecto USHAKOVA, T., "La política de empleo de la OIT y su influencia en el modelo español", op. cit., p. 17.
} 
macroeconómicas que favorezcan el empleo y políticas activas del mercado laboral, con medidas específicas que aborden la demanda y la oferta de trabajo, así como la cantidad y la calidad del empleo. Debe existir también una coherencia entre la política económica, comercial y de empleo. El trabajo decente implica que haya puestos de trabajo en cantidad suficiente y de una calidad aceptable. No basta con crear empleos. El empleo debe ser digno, con derechos. De ahí que la OIT lleve a cabo recomendaciones relativas a las políticas activas y pasivas de empleo, en los apartados 9, 11 y 12 del Pacto Mundial para el Empleo. Para la organización, una crisis global exige una solución global. La crisis ha puesto de manifiesto la necesidad de colocar el empleo y el trabajo decente en el centro de las estrategias económicas y sociales, y ha resaltado la importancia del papel de la OIT para lograrlo.

No me detendré ahora a considerar si las leyes laborales pueden crear empleo por sí solas. Tampoco discutiré si, en los últimos años, ha existido en España una coherencia entre las políticas públicas, por ejemplo las de índole económica y fiscal, para favorecer el empleo. Con todo, cabe dudar de que las últimas reformas laborales que se han llevado a cabo en España, y en particular la de 2012, hayan sido reformas para fomentar el empleo, según pretendía el gobierno del Partido Popular y quienes las defienden a ultranza. Conviene recordar que, en un estado social de derecho, que protege el derecho al trabajo, la flexiseguridad no puede traducirse en una vuelta al despido ad nutum, o en una privación para el trabajador de las garantías de procedimiento y de las medidas de reparación ${ }^{78}$. Por eso, son discutibles propuestas como la de un contrato único, con una indemnización creciente con la antigüedad, que pretenden reducir la dualidad o segmentación del mercado de trabajo, e igualar el grado de tutela de los trabajadores con contratos de duración indefinida y de duración determinada ${ }^{79}$. Aun así, pueden flexibilizarse algunos

78 GIL, J.L, "Seguridad versus flexibilidad en la protección contra el despido injustificado", en ESCUDERO, R. (coord.), Número especial Aportaciones al debate comunitario sobre "flexiseguridad", Relaciones Laborales: revista crítica de teoría y práctica, $\mathrm{n}^{\circ}$ 15-16, agosto de 2007, pp. 143-175, y GIL, J.L., "La protección contra el despido injustificado a la luz del Convenio núm. 158 de la OIT", en GIL, J.L. (dir.), Reformas laborales frente a la crisis a la luz de los estándares de la OIT. Un análisis crítico desde las perspectivas internacional, nacional y comparada, Editorial Juruá, Lisboa, 2014, pp. 165-166.

${ }^{79}$ En Francia, el debate en torno a la creación de un contrato de trabajo único se abrió en el año 2003. En nuestro país, desde 2009, Fedea ha auspiciado también un contrato de trabajo único, con una indemnización por años de servicio que aumente con la antigüedad. Partidos como Ciudadanos han suscrito la propuesta, que ha vuelto a la actualidad con las sugerencias de algunas organizaciones internacionales, y con el debate exagerado que ha motivado la jurisprudencia del TJUE acerca de la desigualdad de trato con respecto a los trabajadores interinos: vid. SSTJUE de 14 de septiembre, asunto C-596/14, Ana de Diego Porras contra Ministerio de Defensa; asunto C-16/15, María Elena Pérez López contra Servicio Madrileño de Salud (Comunidad de Madrid), y asuntos acumulados C-184/15 et C-197/15, Florentina Martínez Andrés y otro contra Servicio Vasco de Salud y otro. La STJUE (Gran Sala) de 5 de junio de 2018, asunto C-677/16, Luisa Montero Mateos y Agencia Madrileña de Atención Social de la Consejería de Políticas Sociales y Familia de la Comunidad Autónoma de Madrid, ha corregido la doctrina errónea que había establecido el tribunal en el asunto C-596/14, Ana de Diego Porras contra Ministerio de Defensa: vid., en la prensa, ESTEBAN, P., "El TJUE rectifica y niega indemnización a los interinos 'legales' que finalizan contrato", Cinco Días, 6 de junio de 2018. La doctrina ha criticado la posibilidad de establecer un contrato de trabajo único, por considerar que vulnera el derecho al trabajo y el Convenio núm. 158 de la OIT sobre terminación 
aspectos de la institución, como los relativos al campo de aplicación de la protección o a la cuantía de la indemnización por despido improcedente ${ }^{80}$. En una democracia, el legislador goza de un margen de apreciación para regular el alcance de la protección contra el despido injustificado. En 2010 y 2012, el legislador ha modificado el régimen jurídico del despido, que sigue concibiéndose, en teoría, como una ultima ratio, con el objetivo de desplazar el centro de gravedad o el derecho común de protección contra el despido injustificado, de limitar el control del poder del empresario y de reducir las indemnizaciones por despido ${ }^{81}$. Al fortalecer los poderes del empresario y facilitar el despido, las últimas reformas laborales han puesto en entredicho el principio de estabilidad en el empleo.

En épocas de crisis, con tasas elevadas de desempleo, los poderes públicos pueden ceder a la tentación de concentrar los esfuerzos en los aspectos cuantitativos, olvidando así los cualitativos. ¿Suponen los minijobs una alternativa adecuada al desempleo? ${ }^{82}$ ¿Otorgan una protección digna? ¿Sirven para conjurar el peligro de la pobreza y la exclusión social? Cabe incurrir en el prejuicio de que existe una jerarquía entre las necesidades materiales y espirituales y una lógica diacrónica entre los objetivos económicos y sociales y entre la cantidad y la calidad. Desde ese punto de vista, primero habría que cubrir las necesidades materiales y luego las espirituales; habría que fomentar primero la creación de puestos de trabajo, y preocuparse luego de mejorar la calidad del empleo. Pues bien, hay que evitar la contraposición entre el empleo y los derechos. No basta con crear empleos. El empleo debe ser digno, con derechos. La noción de trabajo decente no solo expresa la necesidad de acceder al empleo, sino de que el trabajo sea con derechos, en condiciones saludables

de la relación de trabajo: vid. GIL, J.L., "Seguridad versus flexibilidad en la protección contra el despido injustificado", op. cit., pp. 146 y 147, y La protección contra el despido injustificado a la luz del Convenio núm. 158 de la OIT", cit., 164, y RODRÍGUEZ-PIÑERO, M., "Sobre el contrato de trabajo "único", Relaciones Laborales, $\mathrm{n}^{\circ}$ 10, Sección Editorial, Quincena del 23 de mayo al 8 de junio de 2009, Tomo I, p. 111, La Ley 11842/2009, en http://laleydigital.laley.es, 10 pp. En la prensa, vid. ALONSO, C., "El contrato único como solución al escollo de la extrema dualidad laboral", El Economista, 14 de abril de 2017, y "Tirole, Nobel de Economía: 'El mercado laboral de España sigue siendo muy injusto", Expansión, 5 de mayo de 2017.

${ }^{80}$ GIL, J.L., "Seguridad versus flexibilidad en la protección contra el despido injustificado", op. cit., y "La protección contra el despido injustificado a la luz del Convenio núm. 158 de la OIT", op. cit.

${ }^{81}$ Vid., con detalle, GIL, J.L., "La protección contra el despido injustificado a la luz del Convenio núm. 158 de la OIT", op. cit., pp. 161-229; "Strengthening the power of dismissal in recent labor reforms in Spain", en Comparative Labor Law \& Policy Journal, Volume 35, Number 3, Spring 2014, 31 pp. 413-448, y "La convention $\mathrm{n}^{\circ} 158$ de l'OIT et la protection contre le licenciement injustifié en Espagne", en BADEL, M.; PUJOLAR, O.; SANA-CHAILÉ DE NÉRÉ, S. (Coords.), Des liens et des droits. Mélanges en l'honneur de Jean-Pierre Laborde, Dalloz, Paris, 2015, pp. 663-673.

82 Vid. un resumen de la regulación de los minijobs en Alemania, por ejemplo, en http://minijob.com.de/Rechtliche-Grundlagen-des-Minijobs.html; "Minijob. Diese Regeln sollten Sie kennen", 2 de febrero de 2017, en https://www.optimal-absichern.de/magazin/minijob.php, y "Minijob 2017: Alle Gesetzesänderungen, die Sie als Nebenjobber kennen sollten", en http://www.nebenjob.de/ratgeber_nebenjobs/minijob-2017-aenderungen.html. 
y con una remuneración suficiente ${ }^{83}$. Aun así, muchas personas realizan trabajos inaceptables, con condiciones laborales pésimas.

En España, las últimas reformas laborales han contribuido -0 , al menos, no han servido para hacer frente- al deterioro de la calidad en el empleo. Tras la reforma laboral de 2012, los salarios han bajado ${ }^{84}$, el salario de los nuevos empleos es inferior al de los antiguos ${ }^{85}$ y el salario medio por hora es inferior al de países con un nivel de desarrollo equiparable ${ }^{86}$. Como ha advertido la OIT, el gobierno español debe continuar realizando, en consulta con las organizaciones más representativas de trabajadores y empresarios, todos los esfuerzos necesarios para tener en cuenta, en la medida en que sea posible y apropiado, las necesidades de los trabajadores y de sus familias y los factores económicos mencionados en los aparatados a) y b) del artículo 3 del Convenio núm. 131, sobre la

\footnotetext{
${ }^{83}$ Cfr., por ejemplo, OIT, Estado del trabajo decente en el mundo, Nota informativa, Jornada mundial por el trabajo decente, 7 de octubre de 2015, Oficina de la OIT para España, 2015, pp. 8 ss.

${ }^{84}$ Tras la reforma laboral de 2012, las grandes empresas han reducido los salarios un 10\%: cfr. FUNDACIÓN SAGARDOY y ADECCO, Tercer observatorio de seguimiento de la reforma laboral 2012, Club de Excelencia en Sostenibilidad, Madrid, 2014, p. 15. Dominique Cerri, directora general de InfoJobs, constata que el empleo es de peor calidad que antes de la crisis, y afirma que, "en términos monetarios, los salarios están reforzando las desigualdades: suben los más altos, apenas aguantan los medios y caen los más bajos". Cfr. GARCÍA, A., "Dominique Cerri: 'España tiene que dar solución a sus problemas laborales de temporalidad y salarios bajos", El Economista, 22 de marzo de 2017.

${ }^{85}$ Entre 2006 y 2015, los trabajadores que encuentran empleo por primera vez han ganado de media un $24 \%$ menos que los que ya están en el mercado de trabajo. Es el impacto de la crisis económica, la flexibilidad laboral y otras circunstancias del trabajador y de su empresa. Cfr. IZQUIERDO, M. y REGIL, A., "La evolución del empleo y del paro en el primer trimestre de 2017, según la Encuesta de Población Activa", Banco de España, Notas económicas, 28 de abril de 2017, 9 pp., en http://www.bde.es/f/webbde/SES/Secciones/Publicaciones/InformesBoletinesRevistas/NotasEconomicas/ T2/fich/bene1702-nec5.pdf y, en la prensa, VALVERDE, M., "Los nuevos empleos ganan un 24\% menos que los antiguos", Expansión, 29 de abril de 2017.

${ }^{86}$ Cfr. los datos de Eurostat que recoge el equipo de análisis de Bankinter, y que resumen ESPERANZA, D. y GALERA, C., "Los españoles ganan un 60\% menos que los trabajadores de los países nórdicos", Expansión, 22 de marzo de 2017. Los españoles ocupan el puesto número 16 en el ránking de los mejores sueldos de Europa. Con un salario medio de 9,8 euros la hora, nuestro país está muy por detrás de las remuneraciones de otros países de la Unión Europea, como los nórdicos o los pertenecientes al antiguo Benelux, que ocupan los primeros puestos de los mejor pagados. En España, el salario medio es un 60\% inferior al de países como Dinamarca, Noruega o Suiza, donde se gana más de 25 euros la hora. España está lejos de la remuneración recibida en las grandes economías de Europa, como Francia, país en el que se cobra 14,8 euros de media la hora, Reino Unido, 14,7 euros, o Alemania, 15,3 euros. Asimismo el salario está por debajo del de otros países mediterráneos, como Italia, cuyo sueldo medio es de 12,3 euros. El sueldo de España es también inferior a la media de los salarios por hora de los 33 países que conforman esa lista, que asciende a 10, 66 euros, un 8\% mayor al español. Aun así, los salarios en España son todavía muy superiores al de 17 países europeos. La remuneración más baja se da, sobre todo, en los países del este de Europa, cuyos sueldos se encuentran entre los 1,7 euros y los 8,5 euros la hora. Los países en los que se dan los salarios más bajos son Bulgaria, Rumanía y República de Macedonia, cuyos sueldos no superan los 2 euros. Según otras informaciones, que se apoyan también en los datos que publica Eurostat y ha recogido UGT, los costes por hora trabajada en España ascienden a 21,3 euros, 4,1 euros menos que en la media de la Unión Europea y 8,5 menos que en la zona euro. Esos datos llevan al sindicato a denunciar que la contención de los costes laborales no se traduce en un aumento de la competitividad: cfr. "La hora trabajada en España es 8,5 euros más barata que en la media de la zona euro", El Economista, 16 de abril de 2017. Cfr. también "El sueldo medio en España ronda los 1.600 euros", Expansión, 10 de mayo de 2017, y MURILLO, F.J., "Así es el salario medio en Europa y en España”, Expansión, 13 de mayo de 2017.
} 
fijación de salarios mínimos, y dar a cada uno de esos elementos el peso adecuado para determinar el nivel de los salarios mínimos ${ }^{87}$. Ha aumentado la precariedad, tanto en lo que se refiere a los contratos de duración determinada como a tiempo parcial, sobre todo en algunos sectores, como la sanidad pública ${ }^{88}$. No ha descendido la tasa de temporalidad, muy elevada, y uno de los males endémicos del mercado de trabajo español, junto al desempleo insostenible ${ }^{89}$. Además, en la OCDE, España tiene la tasa más baja en la transición de contratos de duración determinada a contratos de duración indefinida ${ }^{90}$. Pese a que se firman más contratos, son de una duración menor y hay un porcentaje excesivo de puestos de baja cualificación. Por otro lado, la mayoría de los contratos a tiempo

${ }^{87}$ Cfr. OIT, "Cuarto informe complementario: Informe del Comité encargado de examinar la reclamación en la que se alega el incumplimiento por España del Convenio sobre la fijación de salarios mínimos, 1970 (núm. 131), presentada en virtud del artículo 24 de la Constitución de la OIT por la Confederación Sindical de Comisiones Obreras (CCOO) y la Confederación Sindical Unión General de Trabajadores (UGT)", Oficina Internacional del Trabajo, Consejo de Administración, 329. ${ }^{a}$ reunión, Ginebra, 9-24 de marzo de 2017, Vigésimo punto del orden del día, Informe del Director General, GB.329/INS/20/4, 15 de marzo de 2017, párrafo 39, p. 11.

${ }^{88}$ STJUE de 14 de septiembre de 2016, caso María Elena Pérez López contra Servicio Madrileño de Salud (Comunidad de Madrid), y 14 de septiembre de 2016, caso Florentina Martínez Andrés y otro contra Servicio Vasco de Salud y otro. Según el informe La precariedad laboral del colectivo médico. Realidades y propuestas, del Colegio Oficial de Médicos de Barcelona (COMB), uno de cada tres médicos trabaja en condiciones de inestabilidad y la mitad de los facultativos menores de 45 años encadenan contratos de duración determinada. Cfr. un resumen del informe en MOUZO, J., "Uno de cada tres médicos tiene empleos precarios", El País, 16 de junio de 2016.

89 Según los datos de Eurostat, España es el segundo país de la Unión Europea con mayor tasa de temporalidad: a finales de 2016, el 26,1\% de los trabajadores carecen un contrato de trabajo de duración indefinida, prácticamente el doble de la media en la Unión Europea (14,1\%). Cfr. SÁNCHEZ, A., "España es el segundo país de la Unión Europea con más empleo temporal", El País, 2 de mayo de 2017. A juicio de la OIT, el alcance de las últimas reformas laborales, que se han centrado en reducir el coste del despido de los contratos indefinidos, ha sido limitado en su capacidad para alterar las actitudes hacia la reorganización del trabajo en la empresa, y no ha servido para reducir la dualidad o segmentación en el mercado de trabajo: cfr. ILO, Non-standard employment around the world. Understanding challenges, shaping prospects, International Labour Office, Geneva, 2016, p. 78. En España, el elevado porcentaje de contratos de duración determinada es un mal no resuelto, pese a las continuas reformas laborales. En este sentido, Dominique Cerri, directora general del portal de empleo InfoJobs, que opera en España e Italia, considera que, aunque se observa una recuperación del mercado laboral en nuestro país, "lo importante es dar una solución a los problemas que quedan por resolver para que el mercado laboral español se recupere en condiciones óptimas: la temporalidad, los bajos salarios, la elevada tasa de paro entre jóvenes y mayores de 45 años...". Cfr. GARCÍA, A., "Dominique Cerri: 'España tiene que dar solución a sus problemas laborales de temporalidad y salarios bajos", El Economista, 22 de marzo de 2017 y, asimismo, "La duración del contrato temporal en la industria cae a menos de dos meses", El País, 13 de enero de 2016; "Los contratos precarios alcanzaron en 2015 sus máximos históricos", El País, 1 de febrero de 2016; "La firma de contratos marca máximos pero cada vez son más breves", El País, 13 de agosto de 2016; "Más de medio millón de españoles encadena contratos temporales desde hace seis años", Expansión, 29 de enero de 2017; GÓMEZ, MANUEL V., "La reforma laboral cumple cinco años: más empleo, pero de peor calidad", $E l$ País, 10 de febrero de 2017; "Uno de cada tres contratos firmados en enero duraron menos de un mes", $E l$ Economista, 26 de febrero de 2017, y BERNAL ALONSO, M.A., "Empleo: no es oro todo lo que reluce", El Economista, 15 de abril de 2017.

${ }^{90}$ ZANCAJO, S., "España es el país de la OCDE donde menos temporales pasan a ser fijos", El Economista, 20 de marzo de 2017. Apenas uno de cada diez trabajadores con un contrato de duración determinada consigue uno de duración indefinida. 
parcial son no deseados y suscritos por mujeres ${ }^{91}$. Además, el contrato de apoyo a los emprendedores, polémico en lo que hace a la regulación de un periodo de prueba de un año, ha fracasado en el intento de fomentar la creación de empleo estable ${ }^{92}$. Según algunos estudios, el contrato de duración indefinida se ha tornado más inestable. En los últimos años, ha crecido la rotación -las altas y bajas- en el empleo indefinido ${ }^{93}$. En suma, no existe una constancia empírica de que la reforma laboral haya contribuido a la creación de empleo y a la reducción de la tasa de desempleo, todavía muy elevado, pero sabemos que ha facilitado el despido y la devaluación salarial y, con toda verosimilitud, ha hecho posible un aumento de la precariedad. Hoy, la figura del trabajador pobre, que ha vuelto a aparecer, pone en entredicho el modelo de equilibrio entre la eficiencia económica y la justicia social que han establecido los poderes públicos, cuestiona la legitimación política, económica y social del sistema de producción capitalista, puede hacer tambalear los cimientos del sistema laboral y de protección social y supone una amenaza para la pervivencia del paradigma en los albores de la cuarta revolución industrial.

En este sentido, en el informe Sostenibilidad en España 2018, el Observatorio de la Sostenibilidad (OS) señala que, aun siendo estable la tendencia en el cumplimiento, el objetivo de desarrollo sostenible número 8 , sobre la promoción del crecimiento económico sostenido, inclusivo y sostenible, el empleo pleno y productivo y el trabajo decente para todos, es uno de los que presenta mayores problemas, en lo que hace a la pobreza con empleo, la tasa de empleo a tiempo parcial no deseado y el porcentaje de contratos de duración determinada no deseados ${ }^{94}$. En la comparecencia en el Congreso

\footnotetext{
${ }^{91}$ En España, según la OIT, un 60\% de trabajadores a tiempo parcial lo es involuntariamente, porque no encuentra un trabajo a jornada completa. El $72 \%$ de los trabajadores a tiempo parcial son mujeres. Cfr. PASCUAL, R., "OIT alerta: el tiempo parcial no es antesala de un empleo mejor", Cinco Días, 13 de enero de 2017; "Los trabajadores a tiempo parcial crecen un 19,1\% desde 2007 y ya rozan los 2,7 millones", $E l$ Economista, 16 de enero de 2017; CALDERÓN, I., "El empleo a tiempo parcial en España, cuestión de sexo: el 72\% de los puestos están ocupados por mujeres", El Economista, 23 de febrero de 2017, y GÓMEZ, M.V., "España, segundo país de la UE con más subempleo", El País, 24 de mayo de 2017.

${ }^{92}$ El nuevo gobierno socialista pretende derogar esta modalidad de contrato de duración indeterminada. Vid. SERRALLER, M. y VALVERDE, M., “Quince 'golpes' del Gobierno a las empresas, Expansión, 7 de julio de 2018.

${ }^{93} \mathrm{Cfr}$. "La contratación indefinida se asocia cada vez más con la rotación laboral y la precariedad y menos con una relación laboral estable", noticia publicada el 9 de agosto de 2016, en la página web del sindicato CC.OO.: http://www.ccoo.es/noticia:206544--

\%E2\%80\%9CLa_contratacion_indefinida_se_asocia_cada_vez mas_con_la rotacion_laboral_y la prec ariedad y menos con_una relacion_laboral estable\%E2\%80\%9D y, asimismo, "La rotación en el empleo indefinido aumenta tras la reforma laboral", El País, 5 de febrero de 2015, y "La rotación en el empleo indefinido crece en 2015", El País, 7 de febrero de 2016.

${ }^{94}$ En palabras del informe:
}

"Al integrar los valores parciales de los 14 indicadores seleccionados por EUROSTAT para el ODS 8, España queda en la última posición absoluta en ambas modalidades de integración (suma directa y ponderada) entre 29 países con datos completos (UE-28 más Noruega).

De los 13 indicadores seleccionados 9 obtienen la peor puntuación posible y 3 de ellos, no relacionados directamente con el desempleo y con la calidad del empleo, obtienen malos resultados. Solamente 
para presentar el informe de 2017, el Defensor del Pueblo ha señalado que la reforma laboral de 2012 ha tenido un escaso efecto real en el empleo para frenar la contratación de duración determinada. A juicio del Defensor del Pueblo, la reforma laboral no es la culpable de la precariedad, pero sí la ha agudizado, al dar mayor poder al empresario ${ }^{95}$.

\subsection{La protección social como amortiguador social y estabilizador económico}

En fin, el trabajo decente constituye una estrategia integrada que vincula la seguridad social con otras cuestiones laborales, a fin de proporcionar la seguridad de ingresos a un mayor porcentaje de la población. La seguridad social contribuye al logro de la justicia social y de una globalización equitativa ${ }^{96}$. En un contexto de globalización y de crisis financiera y económica, resulta esencial mantener y aun reforzar la protección social, porque desempeña un papel de amortiguador social y estabilizador económico, según subrayan el apartado 12 del Pacto Mundial para el Empleo y el preámbulo de la Recomendación núm. 202 de la OIT, de 2012, sobre los pisos o umbrales de protección social ${ }^{97}$. Sin embargo, en no pocos casos, se han perseguido la consolidación fiscal y la

parecemos encontrarnos bien en productividad en el uso de los recursos, medido a partir de magnitudes macroeconómicas (PIB/DMC): con 2,75 €/kg en 2016, España ocupa la $6^{\mathrm{a}}$ mejor posición en la UE-15 y en la UE-28, por detrás de Holanda, el Reino Unido, Italia y Francia. Pero esta productividad se consigue a costa de los sueldos y de las condiciones de empleo.

Pese a reducirse paulatinamente el desempleo (17,2\% en 2017, la segunda peor tras Grecia, más del doble que la media de la UE-28; 7,7\% de desempleo de larga duración, segunda tras Grecia en 2017; 38,6\% de paro juvenil, segunda peor también tras Grecia), el empleo creado no permite condiciones de vida dignas. La pobreza con empleo alcanza el $13,1 \%$ en 2016, la segunda peor de Europa tras Grecia $(14,1 \%)$ y la tendencia es de incremento desde 2013 (10,5\%).

La tasa española de contratos temporales no deseados alcanza en 2017 el 22,4\%, la mayor de Europa; la de empleo a tiempo parcial el 14,6\%, muy superior entre las mujeres que entre los hombres, y se incrementa desde 2009. Y, además, la seguridad a la hora de trabajar solo se sitúa en valores negativos, por encima de las medias de la UE-28 y de la Zona $€ 19$ ". Vid. Observatorio Sostenibilidad \#SOS18, Estado actual de sostenibilidad en España 2018, cit., pp. 2, 3 y 8 ss y, en la prensa, PRIETO, F. y ALFONSO, C., "De la sostenibilidad en un país llamado España en el año 2018”, El País, 13 de julio de 2018.

95 "El Defensor del Pueblo denuncia el alto coste social de la crisis: "Como siempre en la vida hay ganadores y perdedores", Europa Press, 30 de mayo de 2018, en http://www.europapress.es/epsocial/derechoshumanos/noticia-defensor-pueblo-denuncia-alto-coste-social-crisis-siempre-vida-hay-ganadoresperdedores-20180530142355.html.

${ }_{96}$ Cfr OIT, Seguridad social para la justicia social y una globalización equitativa, Conferencia Internacional del Trabajo, $100^{\mathrm{a}}$ reunión, 2011, Informe VI, Discusión recurrente sobre la protección social (seguridad social) en virtud de la Declaración de la OIT relativa a la justicia social para una globalización equitativa, 2011, Sexto punto del orden del día, Oficina Internacional del Trabajo, Ginebra, 2001, ILC.100/VI, 201 pp., y La seguridad social y la primacía del derecho, Conferencia Internacional del Trabajo, $100^{\mathrm{a}}$ reunión, 2011, Estudio General relativo a los instrumentos de la seguridad social a la luz de la Declaración de 2008 sobre la justicia social para una globalización equitativa, Tercer punto del orden del día: Información y memorias sobre la aplicación de convenios y recomendaciones, Informe de la Comisión de Expertos en Aplicación de Convenios y Recomendaciones (artículos 19, 22 y 35 de la Constitución), Informe III (Parte 1B), Oficina Internacional del Trabajo, Ginebra, 2001, ILC.100/III/1B, 317 pp.

${ }^{97}$ El título oficial de la recomendación es "Pisos de protección social". Al menos en castellano, hubiese sido mejor denominarla "Umbrales de protección social", para evitar toda confusión con el sector inmobiliario. Otras posibilidades quizá hubiesen sido "suelos" o "zócalos". 
reducción de la deuda pública a costa de los derechos sociales. La Declaración del Centenario sobre el Futuro del Trabajo, de 2019, indica que, "al ejercer su mandato constitucional, tomando en consideración las profundas transformaciones en el mundo del trabajo, y al desarrollar su enfoque del futuro del trabajo centrado en las personas, la OIT debe orientar sus esfuerzos a: adoptar y ampliar sistemas de protección social que sean adecuados y sostenibles y estén adaptados a la evolución del mundo del trabajo"98. Asimismo, el fortalecimiento de las capacidades de todas las personas para beneficiarse de las oportunidades de un mundo del trabajo en transición, que constituye la primera de las acciones prioritarias del enfoque del futuro del trabajo fundado en el ser humano, debe orientarse, entre otras cosas, al acceso universal a una protección social completa y sostenible, y medidas efectivas para ayudar a las personas a afrontar las transiciones a lo largo de su vida laboral. En la Declaración del Centenario sobre el Futuro del Trabajo, de 2019, el centro de gravedad se desplaza de la política de promoción del empleo a los derechos inherentes a la persona del trabajador. Siguiendo las recomendaciones de la Comisión Mundial para el Futuro del Trabajo, la Declaración invoca cuatro ámbitos, que mezclan derechos y políticas. Junto al logro efectivo del derecho a la igualdad de género en materia de oportunidades y de trato y al derecho al aprendizaje permanente y a la educación, la Declaración se refiere también a las medidas de protección social y de ayuda a las personas a afrontar las transiciones a lo largo de la vida laboral. No debe olvidarse, sin embargo, que las políticas tienen objetivo que las personas puedan ejercer los derechos.

En España, como en otros países, el derecho a la seguridad social se halla inmerso en un proceso de reforma permanente, de gran complejidad ${ }^{99}$. Con todo, cabe distinguir entre los cambios estructurales, que han ayudado a consolidad el sistema, y que se han llevado a cabo, en general, en el marco del Pacto de Toledo a partir de los años noventa, y las reformas específicas o más coyunturales, ligadas a la última crisis financiera y económica.

En efecto, la última fase de las reformas estructurales está marcada por las recomendaciones del Pacto de Toledo, sobre el análisis de los problemas estructurales de la seguridad y de las principales reformas que deberán acometerse. El Pacto es un informe que aprobó el pleno del Congreso de los Diputados, el 6 de abril de 1995, y que se renovó el 2 de octubre de $2003^{100}$. El documento describe la evolución del sistema español de

\footnotetext{
98 II, A, Xv).

${ }^{99}$ Vid. una visión de conjunto de la reforma del derecho de la seguridad social en España para hacer frente a la crisis en VALLE, J.M. DEL, "La evolución de la normativa de Seguridad Social durante la crisis económica y su ajuste a los compromisos de España con la OIT”, en GIL, J.L. (Dir.), Reformas laborales ante la crisis a la luz de los estándares de la OIT. Un análisis crítico desde las perspectivas internacional, nacional y comparada, Editorial Juruá, Lisboa, 2014, pp. 231 ss., y GIL, J.L. y MARTIN, P., "Le système espagnol de protection sociale à l'épreuve de la crise", en TURQUET, P. (Dir.), La crise de la protection sociale en Europe. Adaptation ou refondation, Preses Universitaires de Rennes, 2015, pp. 53-66.

100 Vid. la resolución del Congreso de los Diputados, de 6 de abril de 1995, BOCG, Congreso de los Diputados, Serie E, número 134, 12 de abril de 1995; la resolución del Congreso de los Diputados, de 2 de
} 
pensiones, analiza los factores que podrían afectarlo en el futuro, y propone quince recomendaciones ${ }^{101}$. Encomienda al Congreso de los Diputados la creación de una ponencia sobre la evolución del sistema de pensiones y de una comisión permanente no legislativa de seguimiento y evaluación de los acuerdos del Pacto de Toledo, que se reúne periódicamente, y en la que participan todos los grupos parlamentarios ${ }^{102}$. El Pacto de Toledo, que surgió del acuerdo entre todas las fuerzas políticas representadas en el Parlamento, ha servido para que las grandes reformas se aprueben por consenso, tras los acuerdos del diálogo social. En general, los grupos parlamentarios discuten en la comisión de seguimiento del Pacto de Toledo a partir de los acuerdos sociales, resultado del diálogo social. El Parlamento aprueba luego las medidas propuestas. Hay, pues, un proceso consensual.

En buena medida, las reformas estructurales de la seguridad social se han realizado en el marco del Pacto de Toledo. Antes de la crisis, se produjeron reformas importantes, en especial en el campo de las pensiones de jubilación y de las prestaciones de desempleo. Así, a partir de 1996, las recomendaciones del Pacto de Toledo han determinado la evolución del sistema de pensiones. En el marco del Pacto de Toledo y del proceso de diálogo social, los interlocutores sociales han firmado varios acuerdos, que se han traducido en reformas importantes del sistema de seguridad social ${ }^{103}$. Durante la etapa democrática, el sistema de pensiones se ha modificado seis ocasiones: en 1985, 1997,

octubre de 2003, BOCG, Congreso de los Diputados, Serie D: General, número 596, 2 de octubre de 2003 y, asimismo, el Informe de evaluación y reforma del Pacto de Toledo (BOCG, IX Legislatura, Congreso de los Diputados, Serie D: General, núm. 513, 31 de enero de 2011). El informe lo había adoptado ya la comisión de presupuestos del Congreso de los Diputados el 30 de marzo de 1995. La aprobación tuvo su origen en una proposición no de ley del partido catalán Convergència i Unió, que propuso la inclusión de una ponencia (número 154/4) sobre la cuestión de la seguridad social en la comisión de presupuestos del Congreso de los Diputados.

${ }^{101}$ Las recomendaciones son: separación y clarificación de las fuentes de financiación; constitución de reservas; mejoras de las bases; financiación de los regímenes especiales; mejora de los mecanismos de recaudación y lucha contra la economía irregular; simplificación e integración de régimen especiales; integración de la gestión; evolución de las cotizaciones; equidad y carácter contributivo del sistema; edad de jubilación; mantenimiento del poder adquisitivo de las pensiones; reforzamiento del principio de solidaridad; mejora de la gestión; sistema complementario y, en fin, análisis y seguimiento de la evolución del sistema (Título IX).

102 Puede consultarse una información completa de los diarios de sesiones, composición, intervenciones e iniciativas tramitadas $\mathrm{y}$ en tramitación puede consultarse en la página http://www.congreso.es/portal/page/portal/Congreso/Congreso/Organos/Comision?_piref73_7498063_73 _1339256_1339256.next_page=/wc/detalleInformComisiones?idOrgano=343\&idLegislatura=12.

103 Ya en octubre de 1996, el Gobierno, CC.OO. y UGT firmaron el Acuerdo sobre consolidación y racionalización del sistema de Seguridad Social, que dio lugar a la aprobación de la Ley 24/1997, de 15 de julio, del mismo nombre. Más tarde, el 9 de abril de 2001, se suscribió entre el gobierno, CC.OO., CEOE y CEPYME el Acuerdo para la mejora del sistema de protección social, que recogió la Ley 35/2002, de 12 de julio, de medidas para el establecimiento de un sistema de jubilación gradual y flexible. Cabe mencionar también el Acuerdo sobre medidas en materia de Seguridad Social, de 14 de junio de 2006, firmado por el Gobierno, CC.OO., UGT, CEOE y CEPYME, y que motivó la Ley 40/2007, de 4 de diciembre, del mismo nombre. En fin, el acuerdo social y económico para el crecimiento, el empleo y la garantía de las pensiones, firmado el 2 de febrero de 2011 por el gobierno, CC.OO., UGT, CEOE y CEPYME, dio lugar a la Ley 27/2011, de 1 de agosto, sobre la puesta al día, la mejora y la modernización del sistema de seguridad social. 
2002, 2007, 2011 y 2013. Sin embargo, cabe considerar que las reformas más importantes son las de $1985^{104}, 1997^{105}, 2011^{106}$ y $2013^{107}$. De ellas, las de 1997 y 2011 se llevaron a cabo en el marco del Pacto de Toledo, con el acuerdo de los interlocutores sociales y para asegurar la viabilidad futura del sistema. En efecto, el gobierno, los sindicatos UGT y CCOO y las organizaciones empresariales CEOE y CEPYME suscribieron, el 13 de julio de 2006, el acuerdo sobre las medidas para la seguridad social. La Ley 40/2007 de 4 de diciembre, de medidas en materia de seguridad social, da rango legal a una buena parte de los compromisos sobre la acción protectora incluidos en el acuerdo. Por otra parte, el 2 de febrero de 2011, el gobierno y los interlocutores sociales firmaron el acuerdo social y económico para el crecimiento, el empleo y la garantía de las pensiones. La Ley 27/2011, de 1 de agosto, sobre actualización, adecuación y modernización del sistema de Seguridad Social, acoge ese acuerdo y se inscribe en el marco del diálogo permanente que instituye el Pacto de Toledo. Como advierte el Informe del Defensor del Pueblo correspondiente al año 2017, a diferencia de la reforma negociada de las pensiones de 2011, que recibió un amplio apoyo social y político, la Ley 23/2013, de 23 de diciembre, reguladora del factor de sostenibilidad y del índice de revalorización del sistema de pensiones de la Seguridad Social, no es el fruto del diálogo social. El Informe del Defensor del Pueblo analiza la opción del legislador, y lleva a cabo consideraciones sobre el factor de sostenibilidad y las alternativas posibles al modelo de la reforma de $2013^{108}$.

Como se sabe, el sistema español es de reparto, no de capitalización. Ahora, debido a la devaluación salarial y al elevado desempleo, se necesitan casi cuatro recién contratados para pagar la pensión de un nuevo jubilado ${ }^{109}$. Es una de las consecuencias más negativas de las políticas de devaluación salarial de los últimos años y una de las secuelas de la reforma laboral de 2012. Antes de la crisis de 2008, el gasto público en protección social en España se situaba en un nivel relativamente modesto, si se toma como punto de referencia el peso de las prestaciones sociales en proporción al PIB nacional ${ }^{110}$. Con todo,

\footnotetext{
${ }^{104}$ Ley 26/1985, de 31 de julio, de medidas urgentes para la racionalización de la estructura y de la acción protectora de la Seguridad Social (BOE de 1 de agosto de 1985).

${ }^{105}$ Ley 24/1997, de 15 de julio, de Consolidación y Racionalización del Sistema de Seguridad Social (BOE de 16 de julio de 1997).

${ }^{106}$ Ley 27/2011, de 1 de agosto, sobre actualización, adecuación y modernización del sistema de Seguridad Social (BOE de 2 de agosto de 2011). Vid. un resumen en GIL, J.L., « Espagne », Revue de Droit Comparé du Travail et de la Sécurité Sociale, 2011/1, pp. 93 y 94.

${ }^{107}$ Ley 23/2013, de 23 de diciembre, reguladora del Factor de Sostenibilidad y del Índice de Revalorización del Sistema de Pensiones de la Seguridad Social (BOE de 26 de diciembre de 2013).

108 "Defensor del Pueblo cree que reforma de pensiones de 2013 amenaza el sistema", Agencia EFE, 19 de marzo de 2018, en http://www.finanzas.com/noticias/economia/20180319/defensor-pueblo-cree-reforma3805870.html.

${ }^{109}$ Cfr. SÉRVULO, J., “Los nuevos pensionistas cobran más que los recién contratados”, El País, 4 de junio de 2016.

${ }^{110}$ En España, y según datos de Eurostat de 2010, el porcentaje de las prestaciones sociales era del 25,7\% del PIB, y se situaba por debajo de la media europea, que era del 29,4\%. La distribución de las prestaciones sociales era: desempleo: 14,1\% (media de la UE: 6\%); pensiones: 42,4\% (45\% en la UE); prestaciones sanitarias: $35,7 \%$ (37,4 \% en la UE); prestaciones familiares: $6 \%$ (8\% en la UE); ayudas a la vivienda y
} 
debe advertirse que, desde 1999 y hasta 2011, las cuentas de la Seguridad Social se encontraban en superávit. Esa situación de "buena salud" de las cuentas sociales debe atribuirse, en gran medida, al papel positivo del fondo de reserva creado en $1997 \mathrm{y}$ constituido en 2000, cuyos recursos representaban, en 2011, aproximadamente el $6 \%$ del PIB. Sin embargo, el aumento del desempleo y de la deuda pública ha debilitado la financiación del conjunto. Así, el fondo de reserva de la seguridad social se ha reducido de forma drástica. Llegó a tener acumulados más de 66.814 millones de euros a finales de 2011. En unos meses, al haberse utilizado para pagar las pagas extras y las retenciones del IRPF de los nueve millones de pensionistas, se han consumido 19.200 millones, con lo que, el 31 de diciembre de 2016, quedaban 15.020 millones $^{111}$. De este modo, con la presión a que ha sometido al estado de bienestar, la crisis financiera y económica, y sus consecuencias en el mercado laboral, ha suscitado la cuestión de la capacidad de resistencia que puede ofrecer el sistema público de protección social. ¿Cómo ha ayudado a amortiguar los efectos de la crisis? ¿Toca sus límites, debido a la austeridad impuesta a

lucha contra la exclusión social: $1,8 \%$ (3,6\% en la UE). De ese modo, el peso de las prestaciones por desempleo era superior a la media europea. Cfr. GIL, J.L. y MARTIN, P., "Le système espagnol de protection sociale à l'épreuve de la crise", op. cit., p. 54.

${ }^{111}$ El fondo de reserva de la seguridad social se creó en 1997 y se constituyó en 2000 para acumular los excedentes que empezaba a tener, por entonces, la seguridad social, y costear, cuando fuese necesario, sus déficits contributivos. En el número 2 del apartado IX, el Pacto de Toledo señala que "el sistema contributivo debe presentar presupuestos equilibrados. El sistema de pensiones precisa de la constitución de reservas que atenúen los efectos de los ciclos económicos. (...)”. Esa recomendación tuvo su reflejo en la Ley 24/1997, de 15 de julio, de Consolidación y Racionalización del Sistema de Seguridad Social, cuyo artículo 2 modifica el apartado 1 del artículo 91 de la Ley General de la Seguridad Social, y establece que, "con cargo a los excedentes de cotizaciones sociales que puedan resultar de la liquidación de los Presupuestos de la Seguridad Social, de cada ejercicio económico, se dotará el correspondiente Fondo de Reserva, con la finalidad de atender a las necesidades futuras del sistema. (...)". Aunque la Ley 24/1997, de 15 de julio, crea el Fondo de Reserva de la Seguridad Social, hay que esperar hasta el año 2000 para entender que se constituye dicho fondo, tras realizarse la primera dotación de 601,012 millones de euros. En 2012, como consecuencia del deterioro del empleo y los ingresos de la seguridad social por la crisis de 2008, el gobierno empezó a utilizarlo. Ha pasado de tener 66.815 millones de euros en 2011 a poco más de 15.000 millones en la actualidad. Al ritmo actual, el fondo podría quedar totalmente vacío a finales de 2017 o a principios de 2018. Por eso, en los Presupuestos Generales del Estado para 2017, el gobierno prevé emitir deuda antes que vaciar por completo el fondo de reserva. Según las previsiones, se sacarán 7.300 millones del fondo de reserva, que no se vaciará, y el Estado emitirá deuda para prestar hasta 10.192 millones a la Seguridad Social y pagar las pensiones. Cfr. CALDERÓN, I., "La hucha de las pensiones ya no da ni para pagar tres mensualidades", El Economista, 2 de julio de 2016; PASCUAL, R., "El rendimiento de la hucha de las pensiones cae un 52\% hasta julio", Cinco Días, 2 de septiembre de 2016; MAQUEDA, A., "Hay vida aunque se agote la 'hucha de las pensiones"”, El País, 5 de noviembre de 2016; GÓMEZ, M.V., "La Seguridad Social saca 9.500 millones de la hucha de las pensiones", El País, 1 de diciembre de 2016; PASCUAL, R., "El Gobierno baraja emitir deuda antes de vaciar la hucha de las pensiones", Cinco Días, 6 de febrero de 2017, y "Presupuestos Generales del Estado. El Estado emitirá deuda para prestar hasta 10.192 millones a la Seguridad Social y pagar las pensiones", 2 de abril de 2017, en http://www.rtve.es/noticias/20170404/seguridad-social-recibira-prestamo-10192-millones-euros-parapagar-pensiones/1516601.shtml. El fondo se regula en la LGSS (Título I, Capítulo VII, Sección 4a , Fondo de Reserva de la Seguridad Social), en la Ley 28/2003, de 29 de septiembre, reguladora del Fondo de Reserva de la Seguridad Social, en el Real Decreto 337/2004, de 27 de febrero, que desarrolla reglamentariamente la Ley, y en la disposición adicional décima de la Ley 36/2014, de 26 de diciembre de 2014, de Presupuestos Generales del Estado para 2015, por la que se regula el régimen excepcional de disposición de los activos del Fondo de Reserva de la Seguridad Social. 
las finanzas públicas? En otras palabras, ¿asistimos al fortalecimiento de la protección, a la mera redistribución, o incluso a una reducción drástica de los beneficios sociales? Las autoridades españolas han ensayado distintas respuestas. Con todo, la tendencia parece ser hoy el debilitamiento del estado de bienestar, lo que, en definitiva, se corresponde con el papel -tradicionalmente fuerte- de la solidaridad de la familia en la protección social en España.

Así, las reformas más importantes del sistema de pensiones son las de 1985, 1997, 2011 y 2013. De ellas, las de 1997 y 2011 se llevaron a cabo en el marco del Pacto de Toledo, con el acuerdo de los interlocutores sociales y para asegurar la viabilidad futura del sistema. Como advierte el Informe del Defensor del Pueblo correspondiente al año 2017, a diferencia de la reforma negociada de las pensiones de 2011, que recibió un amplio apoyo social y político, la Ley 23/2013, de 23 de diciembre, reguladora del factor de sostenibilidad y del índice de revalorización del sistema de pensiones de la Seguridad Social, no es el fruto del diálogo social. El Informe del Defensor del Pueblo analiza la opción del legislador, y lleva a cabo consideraciones sobre el factor de sostenibilidad y las alternativas posibles al modelo de la reforma de $2013^{112}$.

Por lo que hace a las reformas más coyunturales, vinculadas a la crisis económica y financiera, el Real Decreto-ley 8/2010, de 20 de mayo, por el que se adoptan medidas extraordinarias para la reducción del déficit público, es el origen de los primeros recortes sistemáticos en la protección social. Desde entonces, primero el gobierno socialista de Rodríguez Zapatero y luego el gobierno conservador de Rajoy han aplicado las medidas de austeridad que propugnan o imponen el FMI, el Banco Central Europeo y la Comisión Europea, y que empobrecen a los ciudadanos, sin resolver un problema que requeriría una respuesta política y solidaria del conjunto de los países de la zona euro. Así, cabe mencionar la reducción de la protección por desempleo, o los recortes o el intento de privatización de la gestión en el ámbito de la asistencia sanitaria. Las medidas más polémicas, como el intento de supresión de servicios de urgencias en la Comunidad de Castilla-La Mancha o de privatización de hospitales en la Comunidad de Madrid, motivaron grandes protestas sociales $\mathrm{y}$, a la postre, las paralizaron los jueces y tribunales ${ }^{113}$. Las quejas que recibe el Defensor del Pueblo relativas a las prestaciones previstas en el sistema de Seguridad Social son numerosas y se refieren en su mayoría a pensiones de jubilación, así como a prestaciones y subsidios por desempleo. Son frecuentes, aunque no mayoritarias, las que versan sobre prestaciones por incapacidad, pensiones de viudedad y pensiones no contributivas. En menor medida, se plantean

\footnotetext{
112 Defensor del Pueblo, Informe anual 2017 y debates en las Cortes Generales, Volumen I. 1 Informe de gestión, Madrid, 2018, pp. 553 ss.

${ }^{113}$ Vid. GIL, J.L., "Trabajo decente y reformas laborales", op. cit., pp. 67 ss. 
también ante la institución cuestiones relativas a cotización y recaudación y a la seguridad social internacional ${ }^{114}$.

Sin duda, las medidas de recortes presupuestarios en algunos sectores, como la salud, la educación, o la dependencia, afectan a los más vulnerables. Como constatan los informes del Defensor del Pueblo, han aumentado la desigualdad y la pobreza y la exclusión social, en especial de los grupos más desfavorecidos. El Defensor del Pueblo ha lamentado que, "como siempre en la vida hay ganadores y perdedores". La clase media ha menguado, y ha perdido cerca de tres millones y medio de personas. Los ricos son cada vez más ricos, y los pobres, más pobres. La desigualdad tiene también una dimensión territorial. El crecimiento económico es desigual, y el valor del PIB por habitante no es homogéneo en todo el territorio. Hay un abismo entre las magnitudes macroeconómicas y la situación real de las personas. El mercado de trabajo refleja la mejoría solo en parte, y las organizaciones internacionales y las instancias de la Unión Europea urgen periódicamente al gobierno español a continuar o a proseguir la reforma laboral, para reducir el desempleo, la tasa de temporalidad y la dualidad o segmentación en el mercado de trabajo". ¿No serán esos requerimientos un reflejo de la esquizofrenia o falta de coherencia de las políticas que propugnan esas organizaciones, y que ha denunciado la doctrina? ¿Cabe aplaudir la recuperación económica, y alabar las últimas reformas laborales, e incluso pedir que se profundice en ellas, y, al mismo tiempo, alarmarse de los riesgos que entrañan el aumento de la precariedad, la desigualdad y la pobreza? En los Pensamientos, Pascal escribió que "il y a assez de lumière pour ceux qui ne désirent que de voir et assez d'obscurité pour ceux qui ont une disposition contraire" ${ }^{115}$. Hay bastante luz para quienes quieren ver lo que Pascal llamaba la raison des effets ${ }^{116}$.

\section{Conclusiones}

El ideal del trabajo decente, de carácter consensual, dinámico, dialéctico y universal, se funda en una integración de derechos y políticas. Respuesta de la OIT a la globalización y a la crisis financiera y económica, es un concepto ético-jurídico y un marco integrador de los pilares del mandato constitucional de la OIT: la promoción del empleo, la protección de los derechos en el trabajo, la extensión de la protección social y el fomento del diálogo social, así como el respeto de la igualdad de oportunidades y trato para todas las mujeres y hombres.

\footnotetext{
${ }^{114}$ Defensor del Pueblo, op. cit.. pp. 541 ss.

115 PASCAL, B., Pensées, Fragment Fondement $\mathrm{n}^{\circ}$ 19/21. Cfr. el texto, con un comentario, y la correspondencia del pasaje con la numeración de otras ediciones, como la de Port-Royal de 1670 o la de Brunschvicg de 1897, en http://www.penseesdepascal.fr/Fondement/Fondement19-moderne.php.

116 Vid. http://www.penseesdepascal.fr/Raisons/Raisons.php acerca de la liasse "Raison des effets", quinto o sexto título de la tabla de materias de los Pensamientos. En la filosofía de Pascal, la raison des effets es lo que da razón de la incoherencia aparente de los efectos, y aporta una explicación, bajo la forma de una ley o una regla.
} 
La noción de trabajo decente pretende englobar en un marco común las perspectivas jurídica y económica, la cantidad y calidad del empleo, la seguridad en el trabajo y unos ingresos dignos. Hay un umbral, pero no un techo de trabajo decente. Por eso, la noción puede aplicarse no solo en los países en desarrollo, sino también en las sociedades avanzadas, en las que aún queda un gran trecho para lograr una justicia social plena.

Es una propuesta original sobre el trabajo y el futuro del derecho del trabajo y la protección social en el mundo, distinta al modelo de la flexibilidad que auspicia la Unión Europea. El concepto de trabajo decente traspasa los límites tradicionales del derecho del trabajo e incluso de la seguridad social. El derecho al trabajo decente va más allá de la legislación laboral vigente. Engloba no solo los derechos de los trabajadores dependientes, sino también los de los trabajadores en la economía informal. Abarca incluso la protección social en sentido amplio.

Es un modelo integrado, que invita a un análisis de las complementariedades y posibles contradicciones entre sus componentes. Así, las reformas laborales que permiten o fomentan la bajada generalizada de los salarios, y hacen posible o no combaten la precariedad, deben tener en cuenta, por ejemplo, las repercusiones de la cantidad y calidad del empleo en el sistema de protección social y, en particular, en la sostenibilidad del sistema de pensiones. El elevado desempleo, la degradación de las condiciones de trabajo y la devaluación de los salarios, junto a otras causas, como la mayor esperanza de vida, ponen en peligro el sistema de pensiones.

El concepto de trabajo decente ha sido un éxito en términos políticos, y lo han consagrado las Naciones Unidas como uno de los objetivos del milenio y, más tarde, del desarrollo sostenible. En el marco de sus competencias, el Defensor del Pueblo puede contribuir a la promoción del trabajo decente, un objetivo de desarrollo sostenible cuya consecución es todavía lejana, incluso en los países más avanzados.

\section{Bibliografía citada}

ALLI, BENJAMIN O. (2002.), Principios fundamentales de salud y seguridad en el trabajo, $2^{a}$ edición, Ministerio de Trabajo e Inmigración, Colección Informes de la OIT, núm. 83, Madrid, 301 pp.

AMNISTÍA INTERNACIONAL, Derechos humanos para la dignidad humana. Una introducción a los derechos económicos, sociales y culturales, Amnistía Internacional, Madrid, 2005. 
AUVERGNON, PHILIPPE; GIL, JOSÉ LUIS (2004), “Le droit social espagnol au temps des gouvernements Aznar", Droit Social, novembre 2004, pp. 1011-1020.

AUVERGNON, PHILIPPE (2012), "De Declaración en Declaración de la OIT: El trabajo decente, lema de acompañamiento social de la globalización", en el monográfico La promoción del trabajo decente como respuesta de la OIT ante la crisis económica y financiera, Relaciones Laborales: Revista Crítica de Teoría y Práctica, 2012, nº 15-18, pp. 121-139.

AUVERGNON, PHILIPPE (2014), “À propos de la promotion du 'travail décent' par l'OIT", en MESTRE, Ch.; SACHS-DURAND, C. ; STORCK, M. (dirs.), Le travail humain au carrefour du droit et de la sociologie. Hommage en l'honneur du Professeur Nikitas Aliprantis, PUS, Strasbourg, 2014, pp. 343-364.

BAJO, IRENE (2015), "La reforma laboral a la luz de la Carta Social Europea. Convergencias y divergencias entre el Tribunal Constitucional y el Comité Europeo de Derechos Sociales", Revista General de Derecho del Trabajo y de la Seguridad Social, 40, 2015, pp. 153-192.

BONNECHÈRE, MICHÈLE (2007), "L'optique du travail décent", Droit Ouvrier, février 2007, pp. 57 a 74.

BONNECHÈRE, MICHÈLE (2008) “Travail décent et 'modernisation' du droit du travail”, Travail et Emploi, no 113, pp. 91 a 115.

BOUTIN, CHRISTINE (2010), De la mondialisation à l'universalisation : une ambition sociale, Mission présidée par Christine Boutin, Rapport intermédiaire au Président de la République, La documentation française, Paris, décembre 2010, 357 pp.

BUSSER, ESTHER (2009), "El Pacto Mundial para el Empleo de la OIT: su importancia y potencial para España", Revista de la Fundación $1^{\circ}$ de mayo, 8 de octubre de 2009, pp. 19-23.

COMITÉ DE DERECHOS ECONÓMICOS, SOCIALES Y CULTURALES (CDESC) (2016), Observación general núm. 23 (2016) sobre el derecho a condiciones de trabajo equitativas y satisfactorias (artículo 7 del Pacto Internacional de Derechos Económicos, Sociales y Culturales), Naciones Unidas, Consejo Económico y Social, E/C.12/GC/23, 27 de abril de 2016, 23 pp. 
COMISIÓN MUNDIAL SOBRE EL FUTURO DEL TRABAJO (2019), Trabajar para un futuro más prometedor, OIT, Ginebra, 84 pp., disponible en https://www.ilo.org/global/topics/future-of-work/brighter-future/lang--es/index.htm.

DAUGAREILH, ISABELLE (2005), “Avant-propos. L'impact de la mondialisation sur les droits fondamentaux de l'homme au travaill", en DAUGAREILH, ISABELLE (dir.), Mondialisation, travail et droits fondamentaux, Bruylant, Bruxelles, pp. XI a XXXIX.

DEFENSOR DEL PUEBLO (2018), Informe anual 2017 y debates en las Cortes Generales, Volumen I. 1 Informe de gestión, Madrid, 2018, 860 pp., en

https://www.defensordelpueblo.es/wp-

content/uploads/2018/03/Informe_anual_2017_vol.I.1_Gestion.pdf.

EGGER, PHILIPPE; SENGENBERGER, WERNER (2001), "Problemas y políticas del trabajo decente", Boletín Técnico Interamericano de Formación Profesional, Boletín Cinterfor/OIT, no 151 , pp. 27-68.

EUROPEAN COMMITTEE OF SOCIAL RIGHTS (2014), Conclusions XX-3 (2014) (Spain), January 2015, 31 pp.

GHAI, DHARAM (2002), Decent work: Concepts, models and indicators, International Institue for Labour Studies, Discussion Paper Series, n 139, Geneva, 48 pp.

GHAI, DHARAM (2003), "Trabajo decente. Concepto e indicadores", Revista Internacional del Trabajo, Volumen 122, 2003/2, Número monográfico sobre La medición del trabajo decente, pp. 125 a 160.

GHAI, DHARAM (2005), Decent work: Universality and Diversity, International Institute for Labour Staties, Discussion paper, Geneva, 23 pp.

GHAI, DHARAM (ed.) (2006), Decent work: Objectives and Strategies, International Institute for Labour Studies, International Labour Office, Geneva, 241 pp.

GIL, JOSÉ LUIS ; USHAKOVA, TATSIANA (2007), "Le dialogue social sur le mode de l'OIT : consolidation et promotion du tripartisme", en MARTIN, PHILIPPE (dir.), Le dialogue social, modèles et modalités de la régulation juridique en Europe, Presses Universitaires de Bordeaux, Droit Européen, Bordeaux, pp. 97-130.

GIL, JOSÉ LUIS (2011), "Espagne”, Revue de Droit Comparé du Travail et de la Sécurité Sociale, 2011/1, pp. 93 y 94. 
GIL, JOSÉ LUIS (2012), "Concepto de trabajo decente", en el monográfico La promoción del trabajo decente como respuesta de la OIT ante la crisis económica y financiera, Relaciones Laborales: Revista Crítica de Teoría y Práctica, 2012, n 15-18, pp. 77-120.

GIL, JOSÉ LUIS (2014a), "Globalización y empleo: Propuestas de la OIT para un desarrollo sostenible", Aranzadi Social: Revista Doctrinal, ISSN 1889-1209, n 11, febrero 2014, pp. 39-82, y, asimismo, en www.aranzadidigital.es, BIB 2014\118, 31 pp.

GIL, JOSÉ LUIS (2014b), "The Protection of Fundamental Rights at Work: The ILO Decent Work Approach", en CARBY-HALL, JO (ed.), Essays on human rights. A celebration of the life of Dr. Janusz, Kochanowski, Ius et Lex, Warsaw, pp. 193-230.

GIL, JOSÉ LUIS (2014c), "La protección contra el despido injustificado a la luz del Convenio núm. 158 de la OIT", en GIL, J.L (dir.), Reformas laborales frente a la crisis a la luz de los estándares de la OIT. Un análisis crítico desde las perspectivas internacional, nacional y comparada, Editorial Juruá, Lisboa, pp. 161-229.

GIL, JOSÉ LUIS (2014d), "Strengthening the power of dismissal in recent labor reforms in Spain", Comparative Labor Law \& Policy Journal, Volume 35, Number 3, Spring 2014, pp. 413-448.

GIL, JOSÉ LUIS (2014e), "L'arbitrage obligatoire en Espagne à l'épreuve du droit international du travail", Revue de Droit Comparé du Travail et de la Sécurité Sociale, Université de Bordeaux, 2014-2, pp. 56-65.

GIL, JOSÉ LUIS (dir.) (2014), Reformas laborales frente a la crisis a la luz de los estándares de la OIT. Un análisis crítico desde las perspectivas internacional, nacional y comparada, Editorial Juruá, Lisboa, 379 pp.

GIL, JOSÉ LUIS (2015a), "La convention no 158 de l'OIT et la protection contre le licenciement injustifié en Espagne", en BADEL, MARISE; PUJOLAR, OLIVIER; SANA-CHAILÉ DE NÉRÉ, SANDRINE (coords.), Des liens et des droits. Mélanges en l'honneur de Jean-Pierre Laborde, Dalloz, Paris, pp. 663-673.

GIL, JOSÉ LUIS (2015b), "Justicia social y acción normativa de la OIT", Revista Internacional y Comparada de Relaciones Laborales y Derecho del Empleo, Vol. 3, $\mathrm{n}^{\circ} 4$, 2015, pp. 1-50.

GIL, JOSÉ LUIS (2015c), “Contrattazione collettiva decentrata e produttività nel settore della produzione di automobili in Spagna", Giornale di diritto del lavoro e di relazioni industriali, n. 146/2015, 2, pp. 295-313.

GIL, JOSÉ LUIS; MARTIN, PHILIPPE (2015), "Le système espagnol de protection sociale à l'épreuve de la crise", en TURQUET, PASCALE (dir.), La crise de la protection 
sociale en Europe. Adaptation ou refondation, Presses Universitaires de Rennes, Collection Économie et Société, pp. 53-66.

GIL, JOSÉ LUIS (2016a), "Globalización y universalidad del derecho: la lex mercatoria y el derecho internacional del trabajo en el mercado global", Revista Internacional y Comparada de Relaciones Laborales y Derecho del Empleo, Vol. 4, no 2, 2016, pp. 83128.

GIL, JOSÉ LUIS (2016b), "Il lavoro nella Costituzione e nelle Dichiarazioni dell'OIL", en CORTI, MATTEO (a cura di), Il lavoro nelle carte internazionali, Vita e Pensiero, Richerche Diritto, Milano, pp. 21-58.

GIL, JOSÉ LUIS (2017a), "La dimensión social de la globalización en los instrumentos de la OIT', Revista Internacional y Comparada de Relaciones Laborales y Derecho del Trabajo, Vol. 5, nº 1, 2017, pp. 236-285.

GIL, JOSÉ LUIS (2017b), “Trabajo decente y reformas laborales”, en GIL, J.L. (coord.), "Eficiencia económica y protección social”, número monográfico de la Revista Derecho Social y Empresa, núm. 7, julio de 2017, Dykinson, Madrid, pp. 21-78.

GIL, JOSÉ LUIS (2017c), "Los principios y derechos fundamentales en el trabajo como orden público social universal", en AA.VV., El futuro del trabajo que queremos, Volumen II, "Conversación IV. La gobernanza del trabajo", Conferencia Nacional Tripartita, 28 de marzo de 2017, Palacio de Zurbano, Madrid, Iniciativa del Centenario de la OIT (1919-2019), Madrid, Organización Internacional del Trabajo y Ministerio de Empleo y Seguridad Social, pp. 503 - 518.

HESSEL, ROGER (2008), Analyse comparative $d u$ dialogue social dans les administrations centrales des États membres de l'UE, Étude de la présidence de l'UE, Direction Générale de l'Administration et de la Fonction Publique, Institut Européen d'Administration Publique, Ministère du Budget, des Comptes Publics et de la Fonction Publique, Collection Études et Perspectives, décembre 2008, 110 pp., en https://www.fonction-

publique.gouv.fr/files/files/publications/etudes_perspectives/analyse_comparative_dialo gue_social_fr.pdf.

HUGHES, STEVE; HAWORTH, NIGEL (2011), The International Labour Organization (ILO). Coming in from the cold, Routledge, Global Institutions, London and New York, 123 pp.

IZQUIERDO, M. y REGIL, A., "La evolución del empleo y del paro en el primer trimestre de 2017, según la Encuesta de Población Activa", Banco de España, Notas 
económicas, 28 de abril de 2017, 9 pp., en http://www.bde.es/f/webbde/SES/Secciones/Publicaciones/InformesBoletinesRevistas/ NotasEconomicas/T2/fich/bene1702-nec5.pdf.

MAUPAIN, FRANCIS (2005), "La 'valeur ajoutée' de la déclaration relative aux principes et droits fondamentaux au travail pour la cohérence et l'efficacité de l'action normative de l'OIT", en DAUGAREILH, I. (dir.), Mondialisation, travail et droits fondamentaux, Bruylant, Bruxelles, 2005, pp. 1-56.

MAUPAIN, FRANCIS (2009), "Nouvelle fondation ou nouvelle façade ? La déclaration de l'OIT sur la justice sociale pour une mondialisation équitable", Droits fondamentaux, n. 7, janvier 2008-décembre 2009, 38 pp., disponible en http://www.droitsfondamentaux.org/.

MUSSO, P. y SUPIOT, A. (dirs.), Qu'est qu'un régime de travail réellement humain?, Hermann, Paris, 2018, 525 pp.

OBSERVATORIO DE LA SOSTENIBILIDAD (OS) (2018), Sostenibilidad en España 2018, 14 pp., en http://www.observatoriosostenibilidad.com./.

OIT (1998), Declaración de la OIT relativa a los principios y derechos fundamentales en el trabajo, adoptada por la Conferencia Internacional del Trabajo en su octogésima sexta reunión, 18 de junio de 1998 (Anexo revisado, 15 de junio de 2010), $2^{a}$ edición con anexo revisado, Oficina Internacional del Trabajo, Ginebra, 18 pp., en https://www.ilo.org/wcmsp5/groups/public/---ed_norm/---

declaration/documents/publication/wcms 467655.pdf.

OIT (1999), Memoria del Director General: Trabajo decente, Conferencia Internacional del Trabajo, 87 a reunión, Ginebra, junio de 1999, 82 pp., en https://www.ilo.org/public/spanish/standards/relm/ilc/ilc87/rep-i.htm.

OIT (2005), Estado del trabajo decente en el mundo, Nota informativa, Jornada mundial por el trabajo decente, 7 de octubre de 2015, Oficina de la OIT para España, 2015, 35 pp, en http://www.ugt.es/sites/default/files/node_gallery/Galera\%20UGT/Informe_OIT_Trabajo_Decente_en_el_Mundo.pdf.

OIT (2008), Declaración de la OIT sobre la justicia social para una globalización equitativa, adoptada por la Conferencia Internacional del Trabajo en su nonagésima séptima reunión, Ginebra, 10 de junio de 2008, Ginebra, 27 pp. en https://www.ilo.org/wcmsp5/groups/public/---dgreports/--cabinet/documents/genericdocument/wcms_371206.pdf. 
OIT (2009), Para recuperarse de la crisis: Un Pacto Mundial para el Empleo, adoptado por la Conferencia Internacional del Trabajo en su nonagésima octava reunión, Ginebra, 19 de junio de 2009, 26 pp., en https://www.ilo.org/wcmsp5/groups/public/---ed_norm/--relconf/documents/meetingdocument/wcms_115078.pdf.

OIT (2011a), La seguridad social y la primacía del derecho, Conferencia Internacional del Trabajo, 100ª reunión, 2011, Estudio General relativo a los instrumentos de seguridad social a la luz de la Declaración de 2008 sobre la justicia social para una globalización equitativa, Tercer punto del orden del día: información y memorias sobre la aplicación de convenios y recomendaciones, Informe de la Comisión de Expertos en Aplicación de Convenios y Recomendaciones (artículos 19, 22 y 35 de la Constitución), Informe III (Parte 1B), Oficina Internacional del Trabajo, Ginebra, 312 pp., en https://www.ilo.org/secsoc/information-resources/publications-and-tools/conferencedocuments/WCMS_221587/lang--en/index.htm.

OIT (2011b), Seguridad social para la justicia social y una globalización equitativa, Discusión recurrente sobre la protección social (seguridad social) en virtud de la Declaración de la OIT relativa a la justicia social para una globalización equitativa, 2011, Conferencia Internacional del Trabajo, 100. a reunión, 2011 Sexto punto del orden del día, Informe VI, ILC.100/VI, Oficina Internacional del Trabajo, Ginebra, 201 pp., en https://www.ilo.org/secsoc/information-resources/publications-and-tools/conferencedocuments/WCMS_SECSOC_22400/lang--es/index.htm.

OIT (2013a), Diálogo social. Discusión recurrente en el marco de la Declaración de la OIT sobre la justicia social para una globalización equitativa, Conferencia Internacional del Trabajo, 102a reunión, 2013, Informe VI, ILC.102/VI, Oficina Internacional del Trabajo, Ginebra, 117 pp., en https://www.ilo.org/ilc/ILCSessions/previoussessions/102/reports/reports-submitted/WCMS_211063/lang--es/index.htm.

OIT (2013b), Le dialogue social tripartite au niveau national. Guide de l'OIT pour une meilleure gouvernance, OIT, Genève, 2013, 306 pp., en https://www.ilo.org/ifpdial/information-resources/publications/WCMS_303210/lang-fr/index.htm.

OIT (2014), 371.er informe del Comité de Libertad Sindical, Consejo de Administración, 320. a reunión, Ginebra, 13-27 de marzo de 2014, GB.320/INS/12, Oficina Internacional del Trabajo, Ginebra, 299 pp., en https://www.ilo.org/wcmsp5/groups/public/--ed_norm/---relconf/documents/meetingdocument/wcms_239691.pdf.

OIT (2016), 380 informe del Comité de Libertad Sindical, Consejo de Administración, 
328. ${ }^{\text {a }}$ reunión, Ginebra, 27 de octubre - 10 de noviembre de 2016, GB.328/INS/14, Oficina Internacional del Trabajo, Ginebra, 325 pp., en https://www.ilo.org/wcmsp5/groups/public/---ed_norm/--relconf/documents/meetingdocument/wcms 534574.pdf.

OIT (2017), "Cuarto informe complementario: Informe del Comité encargado de examinar la reclamación en la que se alega el incumplimiento por España del Convenio sobre la fijación de salarios mínimos, 1970 (núm. 131), presentada en virtud del artículo 24 de la Constitución de la OIT por la Confederación Sindical de Comisiones Obreras (CCOO) y la Confederación Sindical Unión General de Trabajadores (UGT)”, Oficina Internacional del Trabajo, Consejo de Administración, 329. a reunión, Ginebra, 9-24 de marzo de 2017, Vigésimo punto del orden del día, Informe del Director General, GB.329/INS/20/4, 15 de marzo de 2017, 13 pp., en https://www.ilo.org/gb/GBSessions/previous-sessions/GB329/ins/WCMS 548758/lang-es/index.htm.

OIT (2019a), Documento final del centenario de la OIT, Informe IV, Cuarto punto del orden del día, Conferencia Internacional del Trabajo, 108. ${ }^{a}$ reunión, 2019, Oficina Internacional del Trabajo, Ginebra, ILC.108/IV, 11 pp., disponible en https://www.ilo.org/ilc/ILCSessions/108/reports/reports-to-theconference/WCMS 700629/lang--es/index.htm.

OIT (2019b), Seguridad y salud en el centro del futuro del trabajo. Aprovechar 100 años de experiencia, Oficina Internacional del Trabajo, Ginebra, 79 pp., disponbile en https://www.ilo.org/wcmsp5/groups/public/---dgreports/--dcomm/documents/publication/wcms_686762.pdf.

PECCOUD, DOMINIQUE (dir.) (2006), El trabajo decente. Puntos de vista filosóficos y espirituales, OIT, Madrid, $193 \mathrm{pp}$.

RODGERS, GERRY (2002), "El trabajo decente como una meta para la economía global”, Boletín Técnico Interamericano de Formación Profesional, Boletín Cinterfor/OIT, $\mathrm{n}^{\circ}$ 153, pp. 9-28.

RODGERS, GERRY; KUPTSCH, CRISTIANE (eds.) (2008), Pursuing decent work goals: Priorities for research, International Institute for Labour Studies, Geneva, 88 pp., en https://www.ilo.org/wcmsp5/groups/public/---dgreports/--inst/documents/publication/wcms_193766.pdf.

RODGERS, GERRY; LEE, EDDY; SWEPSTON, LEE; VAN DAELE, JASMIEN (2009), La OIT y la lucha por la justicia social, 1919-2009, OIT, Ginebra, 292 pp., en 
https://www.ilo.org/global/publications/ilo-bookstore/orderonline/books/WCMS_104680/lang--es/index.htm.

RODRÍGUEZ-PIÑERO, MIGUEL (2009), "Sobre el contrato de trabajo 'único", Relaciones Laborales, $\mathrm{n}^{\circ} 10$, Sección Editorial, Quincena del 23 de mayo al 8 de junio de 2009, Tomo I, p. 111, La Ley 11842/2009, en http://laleydigital.es, 10 pp.

SALCEDO, M ${ }^{a}$ CARMEN (2015a), "Reformas legislativas, incumplimientos de la Carta Social Europea y su invocación en los órganos judiciales", Fundación Centro de Estudios Andaluces, Sevilla, Colección Actual, 73, julio de 2015, 35 pp., en https://www.centrodeestudiosandaluces.es/datos/publicaciones/Acc73_ok_22072015.pd f.

SALCEDO, Ma CARMEN (2015b), "La aplicación de la Carta Social Europea por los órganos jurisdiccionales: cuestiones conflictivas y argumentos para superarlas", Editorial Bomarzo, 4 de octubre de 2015, en http://editorialbomarzo.es/la-aplicacion-de-la-cartasocial-europea-por-los-organos-jurisdiccionales-cuestiones-conflictivas-y-argumentospara-superarlas/.

SERVAIS, JEAN-MICHEL (2004), "Política de trabajo decente y mundialización. Reflexiones sobre un planteamiento jurídico renovado", Revista Internacional del Trabajo, Vol. 123, 2004/1-2, pp. 18-53.

SERVAIS, JEAN-MICHEL (2011), "La OIT et le travail décent. La difficile médiation entre croissance, création d'emploi et protection des travailleurs", Revue de Droit Comparé du Travail et de la Sécurité Sociale, 2011/1, pp. 71 a 80.

SERVAIS, JEAN-MICHEL (2012), "El trabajo decente: la visión de la OIT y su puesta en práctica", en el monográfico La promoción del trabajo decente como respuesta de la OIT ante la crisis económica y financiera, Relaciones Laborales: Revista Crítica de Teoría y Práctica, 2012, n 15-18, pp. 141-166.

SOMAVÍA, JUAN (2006), El Programa de trabajo decente de la OIT como aspiración de las personas: inserción de los valores y la ética en la economía global, en PECCOUD, D. (dir.), El trabajo decente. Puntos de vista filosóficos y espirituales, OIT, Madrid, pp. 3-12.

SOMAVÍA, JUAN (2008), Prefacio, en Declaración de la OIT sobre la justicia social para una globalización equitativa, Ginebra 2008, p. 1-4. 
SUPIOT, ALAIN (2004), "Du nouveau au self service normatif : la responsabilité sociale des entreprises", en AA.VV., Analyse juridique et valeurs en droit social. Mélanges en l'honneur de Jean Pélissier, Dalloz, Paris, pp. 541-558.

SUPIOT, ALAIN (2006), "La place de la sécurité sociale dans le système des normes internationales du travail", Semaine Sociale Lamy, Supplément, 4 septembre 2006, $\mathrm{n}^{\circ}$ 1272, pp. 7-10.

SUPIOT, ALAIN (2010), L'esprit de Philadelphie. La justice sociale face au marché, Seuil, Paris, 178 pp.

SUPIOT, ALAIN (2015), La Gouvernance par les nombres. Cours au Collège de France (2012-2014), Fayard, Paris, 512 pp.

SUPIOT, ALAIN (2016), "Las vías de una verdadera reforma del derecho del trabajo", traducción al castellano, a cargo de GIL, J.L., del prólogo a SUPIOT, A. (dir.), Au-delà de l'emploi: Les voies d'une vraie réforme du droit du travail, Flammarion, Paris, 2016, Derecho de las relaciones laborales, mensual, n. 5, mayo 2016, pp. 500-519.

SUSTAINABLE DEVELOPMENT SOLUTIONS NETWORK (2018), SDG Index and Dashboards Report 2018. Global Responsibilities. Implementing the Goals, Bertelsmann and Sustainable Development Solutions Network, July 2018, 476 pp., en https://sdgindex.org/reports/sdg-index-and-dashboards-2018/.

USHAKOVA, TATSIANA (2012), "El trabajo decente el contexto de la migración internacional", en el monográfico La promoción del trabajo decente como respuesta de la OIT ante la crisis económica y financiera, Relaciones Laborales: Revista Crítica de Teoría y Práctica, 2012, nº 15-18, pp. 235-258.

USHAKOVA, TATSIANA (2014), "La política de empleo de la OIT y su influencia en el modelo español”, Trabajo. Revista de la Asociación Estatal de Centros Universitarios de Relaciones Laborales y Ciencias del Trabajo, n ${ }^{\circ} 30$, Enero-Junio 2014, Universidad de Huelva, Huelva, Junio 2014, pp. 17-34.

VALLE, J.M. DEL (2014), "La evolución de la normativa de Seguridad Social durante la crisis económica y su ajuste a los compromisos de España con la OIT”, en GIL, J.L. (Dir.), Reformas laborales ante la crisis a la luz de los estándares de la OIT. Un análisis crítico desde las perspectivas internacional, nacional y comparada, Editorial Juruá, Lisboa, 2014, pp. 231 ss. 